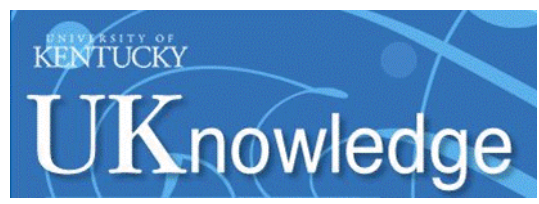

University of Kentucky

UKnowledge

8-2020

\title{
Nanoceria Distribution and Effects Are Mouse-Strain Dependent
}

Robert A. Yokel

University of Kentucky, ryokel@email.uky.edu

Michael T. Tseng

University of Louisville

D. Allan Butterfield

University of Kentucky, david.butterfield@uky.edu

Matthew L. Hancock

University of Kentucky, matthew.hancock@uky.edu

See next page for additional authors

Right click to open a feedback form in a new tab to let us know how this document benefits you. Follow this and additional works at: https://uknowledge.uky.edu/ps_facpub

Part of the Chemical Engineering Commons, Chemistry Commons, Pharmacy and Pharmaceutical Sciences Commons, and the Statistics and Probability Commons 


\title{
Nanoceria Distribution and Effects Are Mouse-Strain Dependent
}

\author{
Digital Object Identifier (DOI) \\ https://doi.org/10.1080/17435390.2020.1770887
}

\section{Notes/Citation Information}

Published in Nanotoxicology, v. 14, issue 6.

(C) 2020 Informa UK Limited, trading as Taylor \& Francis Group

This is an Accepted Manuscript version of the following article, accepted for publication in Nanotoxicology. Yokel, R. A., Tseng, M. T., Butterfield, D. A., Hancock, M. L., Grulke, E. A., Unrine, J. M., Stromberg, A. J., Dozier, A. K., \& Graham, U. M. (2020). Nanoceria distribution and effects are mousestrain dependent. Nanotoxicology, 14(6), 827-846. https://doi.org/10.1080/17435390.2020.1770887

It is deposited under the terms of the Creative Commons Attribution-NonCommercial-NoDerivatives License (https://creativecommons.org/licenses/by-nc-nd/4.0/), which permits non-commercial re-use, distribution, and reproduction in any medium, provided the original work is properly cited, and is not altered, transformed, or built upon in any way.

\section{Authors}

Robert A. Yokel, Michael T. Tseng, D. Allan Butterfield, Matthew L. Hancock, Eric A. Grulke, Jason M. Unrine, Arnold J. Stromberg, Alan K. Dozier, and Uschi M. Graham 


\title{
Nanoceria Distribution and Effects are Mouse-strain Dependent
}

\author{
Robert A. Yokel ${ }^{\mathrm{a}^{*}}$, Michael T. Tseng ${ }^{\mathrm{b} \dagger}$, D. Allan Butterfield ${ }^{\mathrm{c}}$, Matthew L. \\ Hancock $^{\mathrm{d}}$, Eric A. Grulke ${ }^{\mathrm{d} \dagger \dagger}$, Jason M. Unrine ${ }^{\mathrm{e}}$, Arnold J. Stromberg ${ }^{\mathrm{f}}$, Alan K. \\ Dozier $^{\mathrm{g}}$, Uschi M. Graham ${ }^{\mathrm{a}, \mathrm{g}}$ \\ ${ }^{a}$ Pharmaceutical Sciences, University of Kentucky, Lexington, Kentucky, 40536-0596 \\ ${ }^{b}$ Anatomical Sciences \& Neurobiology, University of Louisville, Louisville, Kentucky, 40202 \\ ${ }^{c}$ Chemistry, University of Kentucky, Lexington, Kentucky, 40506-0055 \\ ${ }^{d}$ Chemical and Materials Engineering, University of Kentucky, Lexington, Kentucky, 40506- \\ 0046 \\ ${ }^{e}$ Plant and Soil Sciences, University of Kentucky, Lexington, Kentucky, 40546-0091 \\ ${ }^{f}$ Statistics, University of Kentucky, Lexington, Kentucky, 40536-0082 \\ ${ }^{g}$ CDC, NIOSH, Cincinnati, Ohio, 45226 \\ $†$ Deceased 17 December, 2019. \\ $\dagger$ Deceased 28 November, 2019. \\ * Corresponding author \\ Robert A. Yokel, Ph.D. \\ Department of Pharmaceutical Sciences \\ University of Kentucky Academic Medical Center \\ 335 Todd (College of Pharmacy) Building \\ 789 S. Limestone \\ Lexington, KY, 40536-0596, US \\ phone: 859-257-4855 \\ fax: 859-257-7564 \\ e-mail: ryokel@uky.edu \\ ORCiD: $\underline{000-0001-5188-3972}$
}


Michael T. Tseng, Ph.D.

Anatomical Sciences \& Neurobiology

University of Louisville

Louisville, Kentucky, 40202

D. Allan Butterfield, Ph.D.

Chemistry Department

249 Chemistry-Physics Building

University of Kentucky

Lexington, Kentucky, 40506-0055, US

e-mail: dabcns@uky.edu

ORCiD: 0000-0003-3254-5286

Matthew L. Hancock

Chemical and Materials Engineering Department

A215 ASTeCC

University of Kentucky

Lexington, Kentucky, 40506-0046, US

e-mail: matthew.hancock@uky.edu

ORCiD: 0000-0001-8492-3512

Eric A. Grulke, Ph.D.

Chemical and Materials Engineering Department

University of Kentucky

Lexington, Kentucky, 40506-0046, US

ORCiD: 0000-0002-2982-9037 
Jason M. Unrine, Ph.D.

Department of Plant and Soil Sciences

N-212N Agriculture Science Center North

University of Kentucky

Lexington, Kentucky, 40546, US

e-mail: jason.unrine@uky.edu

ORCiD: 0000-0003-3012-5261

Arnold J. Stromberg, Ph.D.

Department of Statistics

305C Multidisciplinary Science Building

University of Kentucky

Lexington, KY 40536-0082

e-mail: stromberg@uky.edu

ORCiD: 0000-0003-0336-9789

Alan K. Dozier, Ph.D.

Chemical and Biological Monitoring Branch

Health Effects Laboratory Division

National Institute for Occupational Safety \& Health

Centers for Disease Control

Cincinnati, $\mathrm{OH} 45226$

e-mail: xlh5@cdc.gov

Uschi M. Graham, Ph.D.

1525 Bull Lea Road, STE 10

Coldstream Research Park 
Lexington, KY 40511

e-mail: graham@topasol.com

ORCiD: 0000-0002-8585-9732 


\title{
Nanoceria Distribution and Effects are Mouse-strain Dependent
}

\author{
Abstract \\ Prior studies showed nanoparticle clearance was different in C57BL/6 vs BALB/c mice, strains prone to \\ Th1 and Th2 immune responses, respectively. Objective: Assess nanoceria (cerium oxide, $\mathrm{CeO}_{2}$ \\ nanoparticle) uptake time course and organ distribution, cellular and oxidative stress , and bioprocessing \\ as a function of mouse strain. Methods: C57BL/6 and BALB/c female mice were i.p. injected with 10 \\ $\mathrm{mg} / \mathrm{kg}$ nanoceria or vehicle and terminated 0.5 to $24 \mathrm{~h}$ later. Organs were collected for cerium analysis; \\ light and electron microscopy with elemental mapping; and protein carbonyl, IL-1 $\beta$, and caspase-1 \\ determination. Results: Peripheral organ cerium significantly increased, generally more in C57BL/6 \\ mice. Caspase-1 was significantly elevated in the liver at $6 \mathrm{~h}$, to a greater extent in BALB/c mice, \\ suggesting inflammasome pathway activation. Light microscopy revealed greater liver vacuolation in \\ C57BL/6 mice and a nanoceria-induced decrease in BALB/c but not C57BL/6 mice vacuolation. \\ Nanoceria increased spleen lymphoid white pulp cell density in BALB/c but not C57BL/6 mice. Electron \\ microscopy showed intracellular nanoceria particles bioprocessed to form crystalline cerium phosphate \\ nanoneedles. Ferritin accumulation was greatly increased proximal to the nanoceria, forming core-shell- \\ like structures in C57BL/6 but even distribution in BALB/c mice. Conclusions: BALB/c mice were more \\ responsive to nanoceria-induced effects, e.g., liver caspase-1 activation, reduced liver vacuolation, and \\ increased spleen cell density. Nanoceria uptake, initiation of bioprocessing, and crystalline cerium \\ phosphate nanoneedle formation were rapid. Ferritin greatly increased with a macrophage phenotype- \\ dependent distribution. Further study will be needed to understand the mechanisms underlying the \\ observed differences.
}

Key words: BALB/c mice; caspase-1; C57BL/6 mice; ferritin; liver; nanoceria

Word count: $\sim 5675$ 


\section{Introduction}

Nanoparticles (NPs) are cleared by the mononuclear phagocytic system. Differences in immunological reactivity contribute to varying sensitivity to pathogenic agents, tumor growth, and autoimmune diseases. Acquired immunity, a specific and powerful response to pathogens, is classified into Th1 and Th2 responses. C57BL/6 and BALB/c mice are prototypical Th1- and Th2-type mouse strains, respectively, based on their cytokine secretion patterns. T cells from C57BL/6 mice preferentially produce Th1 cytokines with high interferon- $\gamma$ (IFN $\gamma)$ and low interleukin (IL-4) levels, whereas those from BALB/c mice favor Th2 cytokine production with low IFN $\gamma$ and high IL-4 levels. These two mice strains have been extensively studied to evaluate the dependence of pathological processes on genetically determined characteristics of the immune system. C57BL/6 and BALB/c mice have been shown to respond differently to infectious agents (Fornefett et al. 2018); ischemia-induced retinal injury (Shi et al. 2018); antipyrine, vitamin A, and monoamine metabolism (Goverse et al. 2015; Seredenin et al. 1990; Seredenin et al. 2000); and morphine (Di Francesco et al. 1998). Immune status differentially affected $300 \mathrm{~nm}$ PEG hydrogel and $30 \mathrm{~nm}$ carboxylate-coated quantum dot NP clearance in female C57BL/6 and BALB/c mice (Jones et al. 2013).

Nanoceria (nanoscale cerium oxide, cerium dioxide, ceria, $\mathrm{CeO}_{2}$ ) is a family of metal oxide engineered nanomaterials extensively used industrially and shown to have beneficial pharmaceutical properties. Nanoceria are auto-catalytically redox active, cycling between $\mathrm{Ce}^{+++}$ and $\mathrm{Ce}^{++++}$(Deshpande et al. 2005). The surface has oxygen vacancies in its cubic fluorite structure that allow it to easily accept and donate oxygen, providing its catalytic properties. Nanoceria are used as catalysts in diesel fuel, abrasives in chemical mechanical planarization in 
integrated circuit manufacture, as structural supports for catalysts for fuel synthesis applications, in solid oxide fuel cells, and in rechargeable batteries (Feng et al. 2006; Younis et al. 2016). Cerium oxide was selected by the Organisation for Economic Co-operation and Development (OECD) Working Party on Manufactured Nanomaterials as one of 13 representative manufactured nanomaterials for safety testing (OECD 2010).

Nanoceria have been demonstrated to have therapeutic potential for multiple conditions with an oxidative stress/inflammation component including cancer, radiation damage, bacterial infection, sepsis, wounds, stroke-induced ischemia, retinal degeneration, and neurodegenerative diseases (Dhall and Self 2018). Additional applications are cited in the introduction of Yokel et al (Yokel et al. 2019a). Nanoceria have shown utility as nanozymes in sensors for biomolecular recognition (Singh 2016).

Greater NP uptake by M1- or M2-like cells, the cell counterpart to Th1- and Th2-type animals, has not been consistently reported. Uptake of $\sim 200 \mathrm{~nm}$ mesoporous silica particles by macrophage colony-stimulating factor-stimulated macrophages (macrophages polarized toward the M2 phenotype) was $~ 3$-fold greater than uptake by granulocyte macrophage colonystimulating factor-stimulated human monocyte-derived macrophages (macrophages polarized toward the M1 phenotype) (Gallud et al. 2017). Human macrophage uptake of 26 and $41 \mathrm{~nm}$ silica particles by M2-like cells was 224 and 166\%, respectively, of that by M1-like cells (Hoppstädter et al. 2015). Uptake of $15 \mathrm{~nm}$ gold particles by M1- and M2-like human macrophages was comparable ( 0.8 and $0.7 \%$ ), but greater by M2- than M1-like cells for 60 (79 and 72\%) and $100 \mathrm{~nm}$ (95 and 88\%) particles (MacParland et al. 2017). M2-like primary human 
Kupffer cells also took up more $100 \mathrm{~nm}$ particles than M1-like cells (MacParland et al. 2017). In contrast, murine macrophages polarized to the M1 phenotype took up > 3-fold more $130 \mathrm{~nm}$ silica particles than M2 cells (Herd et al. 2015). There was no difference in $\sim 100 \mathrm{~nm}$ polymer NP uptake by C57BL/6 bone marrow derived macrophages that were polarized to M1 or M2 phenotypes or M1 and M2 macrophages harvested from bronchoalveolar lavage fluid of C57BL/6 mice after induction of Th1 or Th2 microenvironments in the lung (McDaniel et al. 2017). Nanoceria is bioprocessed after cell uptake (Graham et al. 2017; Graham et al. 2014; Graham et al. 2018b). The effect of immune status on this process has not been reported. The objective of the present study was to assess the influence of mouse strain on the time course of nanoceria organ and cell uptake, cellular and oxidative stress, and bioprocessing after an acute nanoceria exposure.

\section{Materials and Methods}

\section{Materials}

Nanoceria was synthesized using a hydrothermal method based on Masui et al. (Masui et al. 2002) that included citric acid, resulting in citrate-coated nanoceria. It was dialyzed five times against ten volumes of iso-osmotic citric acid to remove free cerium and unincorporated reactants. We used nanoceria prepared by this method that was previously extensively characterized and shown to have a TEM primary particle diameter of $4.2 \pm 1.2$ (S.D.), an $11 \mathrm{~nm}$ hydrodynamic diameter in DI water, and a zeta potential in DI water at $\mathrm{pH} 7.4$ of $\sim-38 \mathrm{mV}$. The particles were hexagonal with an $\sim$ monolayer citrate coating. Details are reported in Chapter 1 of Matthew Hancock's dissertation (Hancock 2019). A sample of the nanoceria used in this study was characterized to determine its size, shape, diffraction pattern, and cerium valence state, using 
methods described in Sample Preparation and Microscopy, below. Nanoceria synthesized by this method was extensively characterized previously. These characterizations were conducted of the nanoceria ex vivo as typically conducted. It is not possible to extensively characterize in vivo nanomaterials.

\section{Animals}

Forty female 7 to 8 weeks old C57BL/6 and forty BALB/c mice were i.p. injected with $10 \mathrm{mg} / \mathrm{kg}$ nanoceria in iso-osmotic citrate at $\mathrm{pH} 7.4$ or vehicle. The study utilized only females, as did the initial study demonstrating the effect of immune status on NP clearance (Jones et al. 2013) and a more recent study (Fornefett et al. 2018). They were studied in two groups of 20 mice of each strain. To minimize the number of mice, enable consecutive dosing and termination of one mouse from each strain that received the same treatment, and complete a group of 40 mice in one week, three were assigned to each nanoceria treatment group with one control mouse at each termination time. This created a control group for each strain of five mice. They were terminated $0.5,1,3,6$, or $24 \mathrm{~h}$ after nanoceria injection by carbon dioxide asphyxiation and decapitation. This time frame was similar to the initial study demonstrating the effect of immune status on NP clearance (Jones et al. 2013), is sufficient to characterize initial nanoceria uptake and distribution (He et al. 2010; Yokel et al. 2012; Yokel et al. 2009; Yokel et al. 2014) and to see nanoceriainduced oxidative-stress-related effects (Hardas et al. 2010; Hardas et al. 2014; Ma et al. 2014; Nemmar et al. 2017; Rice et al. 2015; Xue et al. 2013). Most importantly it includes the IL-1 $\beta$ and caspase-1 response time to acute insult in cells and mice (Bulugonda et al. 2017; Lin et al. 2016; Okinaga et al. 2015) (Dinesh and Rasool 2017; O'Brien et al. 2017; Uh et al. 2017; Zheng et al. 2017). Selected organs were weighed and collected in clean tubes for elemental analysis 
(second group), in glutaraldehyde/ paraldehyde in Sorenson's buffer for histology (both groups), and flash frozen for oxidative stress indicator assays (both groups). The selected organs were those known to accumulate the majority of nanoceria after its introduction by the i.v., i.p., oral, and pulmonary routes (Aalapati et al. 2013; Catalán et al. 2019; Geraets et al. 2012; He et al. 2010; Hirst et al. 2013; Molina et al. 2014; Park et al. 2018; Rojas et al. 2012; Yokel et al. 2012; Yokel et al. 2009; Yokel et al. 2014).

\section{Cerium Quantitation}

Organ samples from the second group were harvested from the brain (sample site and average weight, in mg) (right hemisphere cortex, 60), heart (apex, 30), lung (superior lobe, 40), kidney (right, 100), spleen (dorsal, 20), and liver (right lobe, 250). Samples were digested with two:one $\mathrm{HNO}_{3}: \mathrm{H}_{2} \mathrm{O}_{2}$ in Teflon vessels in a CEM MARS Express microwave digestion system. Terbium was added as an internal standard. Samples were analyzed compared to standards. Cerium was quantified by inductively coupled plasma mass spectrometry (ICP-MS) (Agilent 7500cx, Agilent Technologies, Inc., Santa Clara, CA) (Yokel et al. 2009). The percent of the nanoceria dose in the organ was calculated from the cerium concentration in the analyzed sample times the mouse's organ weight divided by its nanoceria dose times 100 .

\section{Sample Preparation and Microscopy}

Sectioned liver (right lobe) and spleen (middle third) tissues from the first group were stained with toluidine blue for light microscopy. An image from each of the 40 mice was visually assessed for qualitative histological changes (by MTT). Each liver image was saved as a TIF file and then opened in ImageJ. After scalebar sizing, a 2" x 2" image section was cropped from the 
5.7" x 4.7" original, changed into an 8-bit B/W image, and used for ImageJ tracing of unstained (vacuolated) areas in two 2" 2 " sections (one from the upper left, the other from the upper right of the image). The total area of the cropped section was also measured, which was used to determine the percent total vacuole area of the total 2" x 2" sections. Image J endpoints determined were the number of vacuoles; average vacuole area; sum of the vacuole area; vacuole area as a percentage of the total vacuole area; and average perimeter, Feret, and min Feret of the vacuoles. Each spleen image was saved as a JPEG image. Two 4.25 " x 3.25 " quadrants were cropped from each original image (8.75" x 7.75") in Windows Photo Viewer. Nuclei were counted from each cropped section as a proxy for cell count to determine cell density. The administered dose of nanoceria $(10 \mathrm{mg} / \mathrm{kg})$ would not be expected to produce sufficient intracellular nanoceria agglomerations to be visible with light microscopy, as was seen after much higher nanoceria doses (Catalán et al. 2019; Yokel et al. 2009). Light microscopy would not enable visualization of the primary $(\sim 4 \mathrm{~nm})$ particles. To visualize nanoceria uptake and distribution, selected tissues from both groups were prepared unstained for transmission electron microscopy (TEM) and scanning TEM (STEM). They were assessed by an experimenter blind to the treatment condition (UMG). A NIOSH facilities JEOL 2100F high resolution HRTEM/STEM operated at $200 \mathrm{keV}$ with an analytic pole piece was utilized for the electron microscopy work. Images were recorded using a Gatan Orius 830 4m CCD camera. Data acquisition, analysis, processing for electron energy loss spectroscopy (EELS) and STEM data were done with Gatan Inc. Digital Micrograph software. A Gatan high angle annular dark field detector was used for STEM imaging. All STEM images were acquired using a $0.17 \mathrm{~nm}$ analytical probe, while energy-dispersive spectroscopy (EDS) and EELS analyses were performed using a $1 \mathrm{~nm}$ probe. A Gatan Tridiem filter was used for EELS data acquisition and an 
Oxford AZtec EDS system (Concord, MA) was used for EDS acquisition and elemental mapping. A power law background was subtracted from core edge EELS data acquired from select particles using an integration window of approximately $50 \mathrm{eV}$. To determine if the de novo formed biomineralized iron NPs were ferritin-like, oxygen and iron EELS analyses were conducted on 25 particles in liver from C57BL/6 mice and minerals that contain only $\mathrm{Fe}^{++}$ (amosite) and $\mathrm{Fe}^{+++}$(hematite).

\section{Oxidative Stress Indicator Assays}

Brain (left hemisphere cortex), liver (left lobe), and spleen (ventral) samples from both groups were homogenized with protease inhibitors. Tissues were homogenized with 10 to 15 strokes of a pestle Dounce homogenizer, then diluted with $4 \mu \mathrm{g} / \mathrm{ml}$ leupeptin, $4 \mu \mathrm{g} / \mathrm{ml}$ pepstatin A, $5 \mu \mathrm{g} / \mathrm{ml}$ aprotinin, and 0.2 mM PMSF in RIPA Buffer (all from Sigma). The sample was sonicated for two ten second bursts, on ice between sonications, using a 550 Sonic Dismembrator (Fisher Scientific). Cell debris was pelleted by centrifugation at $8,000 \mathrm{xg}$ for $10 \mathrm{~min}$ at $4{ }^{\circ} \mathrm{C}$. Supernatant was removed and stored at $-80^{\circ} \mathrm{C}$. Protein concentration was determined by the bicinchoninic acid method. Protein carbonyls were determined using the OxyBlot Protein Oxidation Detection Kit (Millipore). IL-1 $\beta$ and caspase-1 were determined using western blotting. Samples were prepared as 30 to $45 \mu \mathrm{g}$ protein/ml in a 1:1 ratio of supernatant:Laemmli sample buffer (50 $\mu 1 \beta$-mercaptoethanol and $950 \mu 12 x$ Laemmli buffer [Bio-Rad]). They were loaded on $8-16 \%$ Criterion $^{\mathrm{TM}}$ TGX Stain-Free ${ }^{\mathrm{TM}}$ Protein Gels (Bio-Rad). The gel was run at 70 Vs for $20 \mathrm{~min}$ then allowed to complete migration at $120 \mathrm{Vs}$ then transferred to a $0.2 \mu \mathrm{m}$ nitrocellulose membrane via a Bio-Rad Trans-Blot Turbo Transfer System at the pre-set Midi Gel setting. The membrane was blocked overnight at room temperature in 5\% BSA in TBS-T, then 
incubated (1:10,000 in TBS-T) with a primary antibody for two h. The blot was then washed of excess antibody with Tris-buffered saline $(0.1 \%$ Tween 20$)$ for three five min washes and incubated $(1: 10,000)$ with a secondary antibody for one $h$, and washed three times. The primary antibodies were anti-IL-1 $\beta$ (Asp 296) rabbit antibody (Cell Signaling Technology) and anticaspase-1 rabbit antibody (Novus Biologicals). The secondary antibody was anti-rabbit goat alkaline phosphatase secondary (Thermo Fisher).

\section{Data Analysis}

The percent of the cerium dose in organs of nanoceria-treated mice was compared by 2-way ANOVA (strain and time) followed by group comparisons using least significant difference (protected LSD) when the ANOVA was significant. A temporal effect was assessed by fitting organ cerium concentrations using a linear or quadratic term as needed. Mouse strain differences in liver vacuole endpoints and spleen cell density was assessed by two-tailed unpaired t-tests of control mice results. Liver vacuolation endpoints, spleen cell density, organ weight, protein carbonyl, IL-1 $\beta$, and caspase-1 results of all treatment groups were compared by 1-way ANOVA and Tukey's multiple comparisons tests. To assess nanoceria-induced temporal changes, tests for linear correlation of time after nanoceria injection (from 0 to $24 \mathrm{~h}$ ) vs the liver endpoints were conducted. Statistical significance was accepted at $\mathrm{p}<0.05$ and the results of statistical tests reported at the level of statistical significance.

\section{Results}

\section{Nanoceria Physicochemical Characterization}


Analysis of a sample of the nanoceria used in this study showed $\sim 4 \mathrm{~nm}$ primary particles as $\sim 11$ $\mathrm{nm}$ agglomerates (Figure $1 \mathrm{C}$ and $\mathrm{D}$ ). EDS showed the nanoceria to be crystalline (Figure 1E, F, and G). EELS showed the nanoceria surface cerium to be predominantly $\mathrm{Ce}^{+++}$(Figure $1 \mathrm{H}$ ), supported by increased surface defect density (Figure $1 \mathrm{E}$ and $\mathrm{G}$ ).

[Figure 1 near here]

\section{Organ Weights and Cerium Concentration}

There were no significant differences in organ weights as a function of mouse strain, nanoceria treatment, or termination time. Nanoceria significantly increased cerium in peripheral organs, generally to a greater extent in C57BL/6 than BALB/c mice (Figure 2). Organ cerium significantly decreased over time in the brain from $0.5 \mathrm{~h}$ to all later times in both mouse strains. There was an overall decrease in cerium in the heart, and an increase in the kidney, liver, and spleen over time. The heart of BALB/c mice had significantly more cerium than C57BL/6 mice at six $\mathrm{h}$ and the liver of $\mathrm{C} 57 \mathrm{BL} / 6$ mice had significantly more cerium than BALB/c mice at $24 \mathrm{~h}$. Over all times there was more cerium in BALB/c than C57BL/6 kidneys and more in C57BL/6 than BALB/c mice spleens (Figure 2).

[Figure 2 near here]

\section{Nanoceria Increased Liver Caspase-1}

There were no statistically significant differences in brain protein carbonyl and IL-1 $\beta$, liver or spleen protein carbonyl, or spleen caspase-1 levels. IL-1 $\beta$ was undetectable in liver or spleen. Caspase-1 was significantly elevated in the liver at $6 \mathrm{~h}$, to a greater extent in BALB/c than C57BL/6 mice (Figure 3) suggesting inflammasome pathway activation. 
[Figure 3 near here]

\section{Liver and Spleen Light Microscopic Differences}

Supplemental Figures 1 and 2 contain light microscopic images of toluidine blue stained liver and spleen from mice that illustrate and were used to determine the below and Table 1 results. Light microscopy revealed greater vacuolation in C57BL/6 than BALB/c mice liver, evidenced as a greater number of vacuoles $(\mathrm{t}=2.924, \mathrm{p}=0.0192)$, sum of the vacuole area $(\mathrm{t}=3.341, \mathrm{p}=$ $0.0102)$; vacuole area as a percentage of the total vacuole area $(\mathrm{t}=3.321, \mathrm{p}=0.0105)$, and larger $\min$ Feret of the vacuoles $(t=2.326, p=0.0485)$. Linear correlation showed the slope of the $\mathrm{BALB} / \mathrm{c}$ mice average vacuole size, perimeter, Feret, and min Feret vs. time were significantly different from zero, suggesting a nanoceria-induced temporal effect. No significant linear correlations were seen in C57BL/6 mice liver vacuole endpoints. ANOVA results of all liver vacuole endpoints were significant at $\mathrm{P}<0.0001$ to 0.0003 . Meaningful differences are a significant increase in average vacuole size in $\mathrm{C} 57 \mathrm{BL} / 6$ mice $0.5 \mathrm{~h}$ after nanoceria and between C57BL/6 and BALB/c mice for all endpoints at various times after nanoceria (Supplemental Figure 3). Spleen cell density was not different between the two mouse strains $(t=0.2574, p=$ 0.8033). C57BL/6 mice spleen cell density was not significantly affected by nanoceria $(F(5,14)=$ 1.663, $\mathrm{p}=0.2080)$, but $\mathrm{BALB} / \mathrm{c}$ mice spleen cell density was $(\mathrm{F}(5,14)=6.008, \mathrm{p}=0.0036)$. Significant differences compared to the controls are shown in Table 1.

[Table 1 near here] 


\section{Nanoceria Uptake and Bioprocessing at the Electron Microscopy Scale}

Electron microscopy showed intracellular nanoceria particles in the liver as early as $0.5 \mathrm{~h}$ after injection, presumably in phagolysosomes (Figure $4 \mathrm{~A}$ and B), surrounded by in situ formed ferritin (biomineralized iron oxy hydroxide $\left(\mathrm{FeHO}_{2}\right)$ (Figure $4 \mathrm{~A}$ to $\left.\mathrm{J}\right)$. Elemental maps verify the nanoceria identity and show association with phosphorus and iron (Figure 4 E2 to E5, F2 to F5, $\mathrm{H} 2$ to $\mathrm{H} 5$, and $\mathrm{J} 2$ to J5). Light microscopic images obtained from same-treated mice can be seen in Supplemental Figure 2.

[Figure 4 near here]

Within $0.5 \mathrm{~h}$ nanoceria bioprocessing had begun in the liver (Figure $5 \mathrm{~A}$ to $\mathrm{D}$ ). Cerium became associated with phosphate to form crystalline cerium phosphate nanoneedles. EDS cerium and cerium phosphate nanoneedle mapping showed epitaxial needle growth on nanoceria, where some nanoceria typically remained at the center due to incomplete or limited transformation that could be controlled by local environmental factors (Figure $5 \mathrm{~K}$ and $\mathrm{L}$ ). Electron diffractograms obtained by focusing the electron beam on the needles where no nanoceria remained confirmed that the crystalline nature of the in vivo formed Ce-phosphate phase corresponds to $\mathrm{CePO}_{4}$ (Figure 5B5, J4, and L4). Bioprocessing in the spleen resulted in cerium phosphate nanoneedles that had the same size range. They were also identified as $\mathrm{CePO}_{4}$ (not shown).

[Figure 5 near here]

\section{Nanoceria Induced Extensive Mouse-strain-dependent Ferritin Formation}

STEM imaging revealed iron (ferritin) in lysosomes in close proximity to cerium-phosphate NPs. This is seen as the EM bright ferritin spots near cerium-phosphate NP agglomerates which are in the yellow squares (Figure 6B and C). Verification of cerium and iron was provided by EDS (Figure 6D1), iron and oxygen by EDS elemental mapping (Figure 6D3 and D4), and cerium, 
phosphate, and iron by EDS mapping (Figure 6E1 to 3). The in situ formed crystalline cerium phosphate nanoneedles were associated with a much greater accumulation of iron (ferritin) particles in the region of nanoceria (red and yellow boxes) at 0.5 and $1 \mathrm{~h}$ (Figure 4A2, B2, C2, and D2) and $24 \mathrm{~h}$ (Figure 6B and C) than normally present in cells (Figure 6A). EDS mapping shows bioprocessed cerium phosphate needles occurring juxtaposed to ferritin (Figure 5A to D). Ferritin particles surround the intact nanoceria and the in situ formed cerium phosphate nanoneedles. Ferritin particle distribution in phagolysosomes was core-shell-like in C57BL/6 (Figure 6B and C) but evenly distributed in BALB/c mice (Figure 6E).

[Figure 6 near here]

EELS oxygen analysis of standard materials (amosite and hematite which contain only $\mathrm{Fe}^{++}$and $\mathrm{Fe}^{+++}$respectively) were performed and the results compared to ferritin. EELS oxygen analysis of amosite and hematite showed a pre-edge in the hematite but not in the amosite spectra (Figure 7A). EELS iron analysis showed a satellite peak in amosite but not hematite, and an $\sim 1 \mathrm{eV}$ shift towards higher voltage in hematite associated with $\mathrm{Fe}^{+++}$(Figure 7B). EELS oxygen analysis comparing the EM light (electron dense) ferritin spots in liver from C57BL/6 mice to hematite showed an $\sim 1 / 3$ reduction of the oxygen pre-peak in ferritin (Figure $7 \mathrm{C}$ ). EELS iron analysis comparing the ferritin spots in liver to hematite revealed a large pre-edge and a satellite peak in ferritin that were absent in hematite, suggesting some $\mathrm{Fe}^{++}$. The $\sim 1 \mathrm{eV}$ shift to the right indicates the presence of $\mathrm{Fe}^{+++}$(Figure $7 \mathrm{D}$ ). These results show that the electron dense particles contain oxygen and iron, predominantly as $\mathrm{Fe}^{+++}$, as stored in ferritin.

[Figure 7 near here]

\section{Discussion}


The mice were exposed to nanoceria in this study via the i.p. route. This is not a typical route of exposure for the human, but a common administration route in rodent studies and an effective nanoceria administration route. The percent of the injection dose in the liver, spleen, kidneys, lungs, heart, and brain (for both mouse strains over all times) was 12, 1.6, 0.78, 0.17, 0.03, and $0.003 \%$, respectively. Injection of a similar-sized nanoceria by the same route resulted in a similar ranking; spleen $>$ liver $>$ lung $>$ kidney $>$ heart $>$ brain (Hirst et al. 2013). Nose-only 8 $\mathrm{nm}$ ceria exposure resulted in a similar kidney to liver cerium mass as the present study, $6 \%$ (Guo et al. 2019). Intratracheal instillation of $6.6 \mathrm{~nm}$ ceria resulted in more cerium in the spleen than the heart, kidneys, or brain, as the present study (He et al. 2010). Nanoceria uptake from the peritoneal cavity resulted in similar cerium organ distribution to that following pulmonary exposure of similar-sized nanoceria (Catalán et al. 2019). Intraperitoneally-administered nanoceria has been reported to be beneficially effective to protect against radiation-induced toxicity (Colon et al. 2010; Popov et al. 2016; Xu et al. 2016), hypoxia-induced lung damage (Arya et al. 2013), ovarian cancer (Giri et al. 2013; Hijaz et al. 2016), lead-induced neurotoxicity (Hosseini et al. 2015), chemically-induced hepatotoxicity (Adebayo et al. 2020; Amin et al. 2011; Amiri et al. 2018; Hashem et al. 2015), pancreatic damage (Khaksar et al. 2017), a model of Parkinson's disease (Hegazy et al. 2017), cardiotoxicity (Sangomla et al. 2018), nephrotoxicity (Hamzeh et al. 2018; Saifi et al. 2019), testicular toxicity (Hamzeh et al. 2019), psoriasis (Domala et al. 2020), streptozotocin-induced diabetes (Khurana et al. 2018; Pourkhalili et al. 2011), and paraquat-induced brain oxidative stress (Domala et al. 2020; Ranjbar et al. 2018). Intraperitoneal nanoceria demonstrated anti-obesity activity (Rocca et al. 2015). Nanoceria administration by this route has also been shown to produce liver and kidney toxicity 
(Negahdary et al. 2012; Poma et al. 2014) and male reproductive dysfunction (Adebayo et al. 2018).

\section{Mouse strain-dependent nanoparticle uptake}

We are aware of only one report of in vivo assessment of the effect of immune status on NP uptake. Clearance from blood of NPs that were much larger $(300 \mathrm{~nm})$ than in this study $(4 \mathrm{~nm})$ was more rapid in female BALB/c than C57BL/6 mice (Jones et al. 2013). Nanoparticle concentration was much higher in liver and spleen than lung, heart, and kidney, as typically seen, and initially (5 min to $2 \mathrm{~h}$ ) higher in $\mathrm{BALB} / \mathrm{c}$ than $\mathrm{C} 57 \mathrm{BL} / 6$ mice liver and spleen. There was no mouse strain difference at $24 \mathrm{~h}$ (Jones et al. 2013). In contrast, the present study showed more cerium in C57BL/6 mice spleen over the five sampling times, and more in the liver at $24 \mathrm{~h}$. The significant decrease in brain cerium after $0.5 \mathrm{~h}$ is probably due to the decline in cerium in the blood within the brain vasculature, as there is little evidence that nanomaterials significantly enter brain parenchyma in the presence of an intact blood-brain barrier (Yokel 2020). The present results and prior studies show rapid nanoceria uptake into organs after its introduction by the intravenous (Molina et al. 2014; Rojas et al. 2012; Yokel et al. 2012; Yokel et al. 2009; Yokel et al. 2013; Yokel et al. 2014), intratracheal (He et al. 2010), and gavage administration routes (He et al. 2010), and the persistence of cerium for up to 5 months, some of which is the administered nanoceria (He et al. 2010), suggesting little change would be expected in the cerium concentration in these organs for weeks or more after nanoceria injection. Many variables might be influencing the differences among the present and Jones et al results, including NP physicochemical properties such as composition, size, shape, surface charge, surface area, and 
reactivity; and NP exposure and post-exposure durations. Mouse strain generally affected NP uptake.

\section{Nanoparticle-induced Caspase-1 Elevation}

Prior studies do not provide clarity on the time course of post-insult caspase-1 elevation. Caspase-1 elevation peaked within a few $\mathrm{h}$ in several murine and human cell lines (Liu et al. 2014; O'Brien et al. 2017), continued to increase over $8 \mathrm{~h}$ in human gingival epithelial cells (Bui et al. 2016), peaked from 3 to $6 \mathrm{~h}$ in the small intestine of mice (Higashimori et al. 2016), but peaked at 1 to 3 days in five cell types from the spleen of radiation-exposed mice (Stoecklein et al. 2015). Caspase-1 elevation reversal, described in cells and animals, has been attributed to cell death (O'Brien et al. 2017). The greater elevation of caspase-1 in BALB/c than $\mathrm{C} 57 \mathrm{BL} / 6$ mice is consistent with reported susceptibility of M2- vs M1-like cells to NP exposure. M2-polarized murine macrophages showed greater proliferation reduction than M1-polarized cells in response to $130 \mathrm{~nm}$ silica particle exposure (Herd et al. 2015). Similarly, viability decreased in M2-, but not M1-polarized human monocyte-derived macrophages exposed to $\sim 200 \mathrm{~nm}$ silica particles (Gallud et al. 2017). The present results are consistent with those of (Herd et al. 2015) who found greater NP uptake by M1-, than M2-like, murine macrophages and less toxicity, suggesting polarization to the M1 phenotype provides a foreign matter coping mechanism (Herd et al. 2015).

\section{Liver and Spleen Light Microscopic Mouse Strain and Nanoceria-treatment Differences}

We are unaware of prior reports of more extensive liver vacuolation in C57BL/6 than BALB/c mice, suggesting this is a novel finding. Increased vacuolation is generally considered an 
adaptive response, intended to limit damage (Henics and Wheatley 1999). C57BL/6 mice have more macrophages activated toward an inflammatory response (M1) that may be consistent with this finding. Increased vacuolation was attributed to osmotic effects associated with disturbed ionic balance during nanoceria uptake (Shubin et al. 2016). Decreased vacuolation is presumably due to a protective (anti-inflammatory/oxidative stress) nanoceria effect. This was seen in $\mathrm{BALB} / \mathrm{c}$ but not C57BL/6 mice, evidenced by significant reductions in liver average vacuole size, perimeter, Feret, and min-Feret over time after nanoceria injection. Nanoceria increased spleen lymphoid white pulp cell density (cells per area) in BALB/c but not C57BL/6 mice (Table 1), a response to chemical and stress insults (Elmore 2006; Vásquez et al. 2015).

\section{Nanoceria Uptake and Bioprocessing at the Electron Microscopy Scale}

Although originally considered very stable, some forms of nanoceria have been shown to dissolve in an acidic, but not neutral, environment, given sufficient time to see the appearance of cerium ions (Cornelis et al. 2011; Dahle et al. 2015; Yokel et al. 2019b) and in vivo, by bioprocessing (Graham et al. 2014; Graham et al. 2017; Graham et al. 2018b). Cerium ions in the presence of phosphate results in formation of cerium phosphate (Graham et al. 2017; Graham et al. 2018b; Zhang et al. 2012), as was reported after i.p. injection of cerium ions and introduction into the lung (Berry et al. 1989). The nanoneedles seen in C57BL/6 and BALB/c mice liver and spleen were identical in form, shape, and size to those seen in human and murine (RAW 264.7) macrophages polarized to M1 and M2 phenotypes (unpublished results). As $\mathrm{Ce}^{+++}$and $\mathrm{Ce}^{++++}$ phosphate have been reported to be highly insoluble $\left(\log \mathrm{K}_{\mathrm{sp}} 10^{-26}\right.$ to $10^{-23}$ ) (Lebedev and Kulyako 1978; Liu and Byrne 1997) and ( $\log \mathrm{K}_{\mathrm{sp}} 10^{-115}$ and 10-34) (Lebedev and Kulyako 1978; 
Li et al. 2005), respectively, the cerium phosphate nanoneedles are predicted to be very persistent.

\section{Ferritin accumulation at the site of nanoceria accumulation}

There was a great increase of biomineralized oxygen- and iron-containing particles ( $\sim 5$ to $15 \mathrm{~nm}$ iron-oxo particles) in the nanoceria-dosed compared to control mice (Figure 6). The presence of oxygen and iron, in addition to a confined size and shape of $\sim 5$ to $12 \mathrm{~nm}$ spheroids, indicate ferritin-like particles (Graham et al. 2020). The $\sim 1 / 3$ reduction of the oxygen edge in ferritin from that seen in the standard hematite (toward the absence as seen in the standard amosite) and the presence of a satellite peak in ferritin (as seen in amosite but not hematite) might be due to several interpretations. They may be due to size or density differences in the highly crystalline $\mathrm{Fe}_{2} \mathrm{O}_{3}$ (hematite) versus ferritin which contains protein (iron enters the protein channels and is precipitated in the ferritin shell). Some $\mathrm{Fe}^{++}$trapped inside the shell may not have been converted to $\mathrm{Fe}^{+++}$. Also, the density of iron states in hematite may not be the same as ferritin iron. Hydroxyl groups can be both electron-donating and electron-withdrawing, depending on whether anti-bonding states are available. The hydroxyl group is electron-withdrawing through sigma bonds and electron-donating through pi bonds, i.e., through anti-bonding states as compared to the double bond to oxygen as in hematite. The results suggest a predominance of $\mathrm{Fe}^{+++}$but some $\mathrm{Fe}^{++}$in the biomineralized oxygen- and iron-containing particles. Iron-oxo "ferritin" particles typically form in protein cages made of ferritin-like protein subunits including dodecameric "Dps", encapsulins or icosahedra (Zeth et al. 2016). It is generally assumed that ferrous iron $\left(\mathrm{Fe}^{++}\right)$binds the ferroxidase center and the oxidized iron $\left(\mathrm{Fe}^{+++}\right)$spontaneously enters the ferritin cage through four channels that go through the protein shell and facilitate the influx and outflux 
of ions that control the formation iron-oxo precipitates. This biomineralization is catalyzed by the presence of active ferroxidase centers lining the inside of the protein shell (Bradley et al. 2014). The formation of iron-oxo particles requires a series of steps including upregulation of iron, oxidation, nucleation, biomineralization, and sequestration. The dense iron-oxo particles can be seen in high-angle annular dark-field-STEM imaging. In the ferritin shell iron forms crystallites of hydrous ferric oxide ferrihydrite with phosphorus present. Ferritin has been shown to increase in response to stress, anoxia, infection, inflammation, trauma, surgery, tissue injury, neoplastic growth, immunological disorders, and inflammatory cytokines in serum (NorthropClewes 2008; You and Wang 2005) and intracellularly (Beck et al. 2002; Larade and Storey 2004; You and Wang 2005). The main purpose of this acute phase protein response is as a cellular defense mechanism to prevent further damage to the affected tissues and to remove harmful molecules (Northrop-Clewes 2008). Induced ferritin protein and/or mRNA in cells has been reported after exposure to sodium arsenite, $\mathrm{H}_{2} \mathrm{O}_{2}$, tert-butylhydroquinone, aqueous extract of cigarette smoke, chemopreventive dithiolethiones, and $5 \mu \mathrm{m}$ diameter silica particles (Bosio et al. 2002; Ghio et al. 2019; Lee and Ho 1995; Pietsch et al. 2003; Tsuji et al. 2000). Intracellular ferritin positively correlated with the extent of iron contamination in single-walled carbon nanotubes (Cammisuli et al. 2018). Induction has also been seen in starfish following LPS stimulation, in marine snail (periwinkle) hepatopancreas during anoxia, and the liver of rats that received a glutathione-deleting agent (phorone), a chemoprotective agent (1,2-dithiole-3-thione), or carbon tetrachloride (Beck et al. 2002; Cairo et al. 1995; Larade and Storey 2004; Primiano et al. 1996; Schiaffonati and Tiberio 1997). Abnormal ferritin deposits containing ferritin protein cages filled with iron-oxo NPs were seen in the globus pallidus of victims of an adult-onset basal ganglia disease that has manifestations similar to Huntington's disease or parkinsonism (Curtis et 
al. 2001) and lung of a Quebec asbestos mining region resident that demonstrated mesothelioma (Graham et al. 2018a). It has been shown that invader NPs with various compositions or structures delivered via different uptake routes (i.e., inhalation and i.v.), can share a common response, specifically, the biomineralization of ferritin NPs (Graham et al. 2017). The significance of iron in biological systems is, therefore, linked to its ability to engage in redox reactions, including the scavenging of free radicals (Graham et al. 2014). Since the oxidation of mobile $\mathrm{Fe}^{++}$ions at ferroxidase centers leads to precipitated $\mathrm{Fe}^{+++}$, it is this catalytic process that affords ferritin with its antioxidant property (Graham et al. 2020). The two studies of human tissue and a study of liver from iron-loaded rats are the only reports we are aware of that showed dense ferritin localization (Sorber et al. 1990). Mice liver ferritin density in the present study was characterized by a close-arrangement and dense packing in phagolysosomes. The biomineralized iron-oxo particles were clearly enriched in phagolysosomes, but only in those that also harbored/contained invader nanoceria or its biotransformation product (cerium phosphate nanoneedles). Compared to the very low ferritin density distribution in nanoceria-free tissue (Figure 6A), the current HRTEM-study found select ceria-containing phagolysosomes that had ferritin neighboring other ferritins with less than a couple nm space between the particles (Figure 6B-E). Particle density cannot be reliably assessed with the 2-dimensional (2D) imaging used in the current study since phagolysosomes are 3D structures and we assume that the ferritin particles distribute throughout the entire organelle. Therefore, to assess the ferritin density distribution in mononuclear phagocytic system organs of C57BL/6 and BALB/c mice affected by ceria, additional work using 3D reconstruction of ferritin containing phagolysosomes via electron tomography will need to be performed in a follow-up study. 


\section{Conclusions}

The greater nanoceria uptake by mononuclear phagocytic system organs of C57BL/6 than $\mathrm{BALB} / \mathrm{c}$ mice may protect against nanoceria-induced effects. BALB/c mice were more responsive to nanoceria-induced effects. They showed greater liver caspase-1 activation, reduced liver vacuolation, and increased spleen cell density than C57BL/6 mice. Nanoceria was rapidly taken up into phagolysosomes and underwent bioprocessing, including association with phosphate and formation of crystalline cerium phosphate nanoneedles. There was a great increase of ferritin that had a different distribution in C57BL/6 than BALB/c mice. Further study will be needed to understand the mechanisms underlying the observed mouse strain differences.

Acknowledgements: This work was supported by the National Institutes of Health [grant number R01GM109195]. The content is solely the responsibility of the authors and does not necessarily represent the official views of the National Institutes of Health or the National Institute for Occupational Safety and Health. The authors gratefully acknowledge Marsha L. Ensor, Shekinah Alfaro, and Shristi Shrestha for their excellent contributions to this research.

Declaration of interest: The authors report no conflict of interest.

\section{References:}

Aalapati S, Ganapathy S, Manapuram S, Anumolu G, Prakya BM. 2013. Toxicity and bioaccumulation of inhaled cerium oxide nanoparticles in CD1 mice. Nanotoxicology 8: 786798.

Adebayo OA, Akinloye O, Adaramoye OA. 2018. Cerium oxide nanoparticle elicits oxidative stress, endocrine imbalance and lowers sperm characteristics in testes of balb/c mice. Andrologia 50: e12920. 
Adebayo OA, Akinloye O, Adaramoye OA. 2020. Cerium oxide nanoparticles attenuate oxidative stress and inflammation in the liver of diethylnitrosamine-treated mice. Biol. Trace Elem. Res. 193: 214-225.

Amin KA, Hassan MS, Awad E-ST, Hashem KS. 2011. The protective effects of cerium oxide nanoparticles against hepatic oxidative damage induced by monocrotaline. Int. J. Nanomed. 6: 143-149.

Amiri FT, Hamzeh M, Beklar SY, Hosseinimehr SJ. 2018. Anti-apoptotic and antioxidant effect of cerium oxide nanoparticles on cyclophosphamide-induced hepatotoxicity. Erciyes Med. J. 40: $148-154$.

Arya A, Sethy NK, Singh SK, Das M, Bhargava K. 2013. Cerium oxide nanoparticles protect rodent lungs from hypobaric hypoxia-induced oxidative stress and inflammation. Int. J. Nanomed. 8: 4507-4520.

Beck G, Ellis TW, Habicht GS, Schluter SF, Marchalonis JJ. 2002. Evolution of the acute phase response: iron release by echinoderm (Asterias forbesi) coelomocytes, and cloning of an echinoderm ferritin molecule. Dev. Comp. Immunol. 26: 11-26.

Berry JP, Masse R, Escaig F, Galle P. 1989. Intracellular localization of cerium. A microanalytical study using an electron microprobe and ionic microanalysis. Hum. Toxicol. 8: 511-520.

Bosio A, Knörr C, Janssen U, Gebel S, Haussmann H-J, Müller T. 2002. Kinetics of gene expression profiling in Swiss 3T3 cells exposed to aqueous extracts of cigarette smoke. Carcinogenesis 23: 741-748.

Bradley JM, Moore GR, Le Brun NE. 2014. Mechanisms of iron mineralization in ferritins: one size does not fit all. JBIC, J. Biol. Inorg. Chem. 19: 775-785.

Bui FQ, Johnson L, Roberts J, Hung S-C, Lee J, Atanasova KR, Huang P-R, Yilmaz Ö, Ojcius DM. 2016. Fusobacterium nucleatum infection of gingival epithelial cells leads to NLRP3 inflammasome-dependent secretion of IL-1 $\beta$ and the danger signals ASC and HMGB1. Cell. Microbiol. 18: 970-981.

Bulugonda RK, Kumar KA, Gangappa D, Beeda H, Philip GH, Muralidhara Rao D, Faisal SM. 2017. Mangiferin from Pueraria tuberosa reduces inflammation via inactivation of NLRP3 inflammasome. Sci. Rep. 7: 42683.

Cairo G, Tacchini L, Pogliaghi G, Anzon E, Tomasi A, Bernelli-Zazzera A. 1995. Induction of ferritin synthesis by oxidative stress. Transcriptional and post-transcriptional regulation by expansion of the "free" iron pool. J. Biol. Chem. 270: 700-703.

Cammisuli F, Giordani S, Gianoncelli A, Rizzardi C, Radillo L, Zweyer M, Da Ros T, Salomé M, Melato M, Pascolo L. 2018. Iron-related toxicity of single-walled carbon nanotubes and crocidolite fibres in human mesothelial cells investigated by Synchrotron XRF microscopy. Sci. Rep. 8: 1-14.

Catalán J, Fascineli ML, Politakos N, Hartikainen M, Garcia MP, Cáceres-Vélez PR, Moreno C, da Silva SW, Morais PC, Norppa H, Moya SE, Azevedo RB. 2019. In vivo toxicological evaluation of polymer brush engineered nanoceria: impact of brush charge. Nanotoxicology 13: 305-325.

Colon J, Hsieh N, Ferguson A, Kupelian P, Seal S, Jenkins DW, Baker CH. 2010. Cerium oxide nanoparticles protect gastrointestinal epithelium from radiation-induced damage by reduction of reactive oxygen species and upregulation of superoxide dismutase 2. Nanomedicine 6: 698-705. 
Cornelis G, Ryan B, McLaughlin MJ, Kirby JK, Beak D, Chittleborough D. 2011. Solubility and batch retention of $\mathrm{CeO}_{2}$ nanoparticles in soils. Environ. Sci. Technol. 45: 2777-2782.

Curtis ARJ, Fey C, Morris CM, Bindoff LA, Ince PG, Chinnery PF, Coulthard A, Jackson MJ, Jackson AP, McHale DP, Hay D, Barker WA, Markham AF, Bates D, Curtist A, Burn J. 2001. Mutation in the gene encoding ferritin light polypeptide causes dominant adult-onset basal ganglia disease. Nat. Genet. 28: 350-354.

Dahle JT, Livi K, Arai Y. 2015. Effects of $\mathrm{pH}$ and phosphate on $\mathrm{CeO}_{2}$ nanoparticle dissolution. Chemosphere 119: 1365-1371.

Deshpande S, Patil S, Kuchibhatla SV, Seal S. 2005. Size dependency variation in lattice parameter and valency states in nanocrystalline cerium oxide. Appl. Phys. Lett. 87: 133113/133111-133113/133113.

Dhall A, Self W. 2018. Cerium oxide nanoparticles: a brief review of their synthesis methods and biomedical applications. Antioxidants 7: 97/91-97/13.

Di Francesco P, Tavazzi B, Gaziano R, Lazzarino G, Casalinuovo IA, Di Pierro D, Garaci E. 1998. Differential effects of acute morphine administrations on polymorphonuclear cell metabolism in various mouse strains. Life Sci. 63: 2167-2174.

Dinesh P, Rasool M. 2017. Berberine, an isoquinoline alkaloid suppresses TXNIP mediated NLRP3 inflammasome activation in MSU crystal stimulated RAW 264.7 macrophages through the upregulation of Nrf2 transcription factor and alleviates MSU crystal induced inflammation in rats. Int. Immunopharmacol. 44: 26-37.

Domala A, Bale S, Godugu C. 2020. Protective effects of nanoceria in imiquimod induced psoriasis by inhibiting the inflammatory responses. Nanomed. (London) 15: 5-22.

Elmore SA. 2006. Enhanced histopathology of the spleen. Toxicol. Pathol. 34: 648-655.

Feng X, Sayle DC, Wang ZL, Paras MS, Santora B, Sutorik AC, Sayle TX, Yang Y, Ding Y, Wang X, Her YS. 2006. Converting ceria polyhedral nanoparticles into single-crystal nanospheres. Science 312: 1504-1508.

Fornefett J, Krause J, Klose K, Fingas F, Hassert R, Benga L, Grunwald T, Müller U, Schrödl W, Baums CG. 2018. Comparative analysis of humoral immune responses and pathologies of $\mathrm{BALB} / \mathrm{c}$ and C57BL/6 wildtype mice experimentally infected with a highly virulent Rodentibacter pneumotropicus (Pasteurella pneumotropica) strain. BMC Microbiol. 18: 45/41-45/11.

Gallud A, Bondarenko O, Feliu N, Kupferschmidt N, Atluri R, Garcia-Bennett A, Fadeel B. 2017. Macrophage activation status determines the internalization of mesoporous silica particles of different sizes: Exploring the role of different pattern recognition receptors. Biomaterials 121: 28-40.

Geraets L, Oomen AG, Schroeter JD, Coleman VA, Cassee FR. 2012. Tissue distribution of inhaled micro- and nano-sized cerium oxide particles in rats: Results from a 28-day exposure study. Toxicol. Sci. 127: 463-473.

Ghio AJ, Soukup JM, Stonehuerner J, Tong H, Richards J, Gilmour MI, Madden MC, Shen Z, Kantrow SP. 2019. Quartz disrupts iron homeostasis in alveolar macrophages to impact a pro-inflammatory effect. Chem. Res. Toxicol. 32: 1737-1747.

Giri S, Karakoti A, Graham RP, Maguire JL, Reilly CM, Seal S, Rattan R, Shridhar V. 2013. Nanoceria: A rare-earth nanoparticle as a novel anti-angiogenic therapeutic agent in ovarian cancer. PLoS ONE 8: e54578.

Goverse G, Olivier BJ, Molenaar R, Knippenberg M, Greuter M, Konijn T, Cook ECL, Beijer MR, Fedor DM, den Haan JMM, Napoli JL, Bouma G, Mebius RE. 2015. Vitamin A 
metabolism and mucosal immune function are distinct between BALB/c and C57BL/6 mice. Eur. J. Immunol. 45: 89-100.

Graham UM, Dozier AK, Oberdörster G, Yokel RA, Molina R, Brain JD, Pinto JM, Weuve J, Bennett DA. 2020. Tissue specific fate of nanomaterials by advanced analytical imaging techniques - A review. Chem. Res. Toxicol. Accepted for publication in the Special Issue Future Nanosafety.

Graham UM, Jacobs G, Yokel RA, Davis BH, Dozier AK, Birch ME, Tseng MT, Oberdörster G, Elder A, DeLouise L. (2017) From dose to response: In vivo nanoparticle processing and potential toxicity. In: L. Tran, M.A. Bañares and R. Rallo (Eds), Modelling the Toxicity of Nanoparticles, Springer, Cham, Switzerland, pp. 71-100.

Graham UM, Oberdörster G, Case B, Dozier A. 2018a. A case study of the translocation, bioprocessing and tissue interactions of EMP following inhalation exposure. Toxicol. Appl. Pharmacol. 361: 81-88.

Graham UM, Tseng MT, Jasinski JB, Yokel RA, Unrine JM, Davis BH, Dozier AK, Hardas SS, Sultana R, Grulke E, Butterfield DA. 2014. In vivo processing of ceria nanoparticles inside liver: Impact on free radical scavenging activity and oxidative stress. ChemPlusChem 79: 1083-1088.

Graham UM, Yokel RA, Dozier AK, Drummy L, Mahalingam K, Tseng MT, Birch E, Fernback J. 2018b. Analytical high-resolution electron microscopy reveals organ specific nanoceria bioprocessing. Toxicol. Pathol. 46: 47-61.

Guo C, Robertson S, Webber RJM, Buckley A, Warren J, Hodgson A, Rappoport JZ, Ignatyev K, Meldrum K, Römer I, Macchiarulo S, Chipman JK, Marczylo T, Leonard MO, Gant TW, Viant MR, Smith R. 2019. Pulmonary toxicity of inhaled nano-sized cerium oxide aerosols in Sprague-Dawley rats. Nanotoxicology 13: 733-750.

Hamzeh M, Amiri FT, Beklar SY, Hosseinimehr SJ. 2018. Nephroprotective effect of cerium oxide nanoparticles on cyclophosphamide-induced nephrotoxicity via anti-apoptotic and antioxidant properties in BALB/c mice. Marmara Pharm. J. 22: 180-189.

Hamzeh M, Karimpour A, Khalatbary AR, Talebpour AF, Hamzeh M, Hosseinimehr SJ, Mohammadi HR. 2019. Cerium oxide nanoparticles protect cyclophosphamide-induced testicular toxicity in mice. Int. J. Prev. Med. 10: 5.

Hancock ML. (2019) Dissertation: The fabrication and characterization of metal oxide nanoparticles employed in environmental toxicity and polymeric nanocomposite applications. Chemical and Materials Engineering, University of Kentucky, UKnowledge, p. 270, https://uknowledge.uky.edu/cme_etds/112. (visited 5/11/2020)

Hardas SS, Butterfield DA, Sultana R, Tseng MT, Dan M, Florence RL, Unrine JM, Graham UM, Wu P, Grulke EA, Yokel RA. 2010. Brain distribution and toxicological evaluation of a systemically delivered engineered nanoscale ceria. Toxicol. Sci. 116: 562-576.

Hardas SS, Sultana R, Warrier G, Dan M, Wu P, Grulke EA, Tseng MT, Unrine JM, Graham UM, Yokel RA, Butterfield DA. 2014. Rat hippocampal responses up to 90 days after a single dose of nanoceria extends a hierarchical oxidative stress model for nanoparticle toxicity. Nanotoxicology 8: 155-166.

Hashem RM, Rashd LA, Hashem KS, Soliman HM. 2015. Cerium oxide nanoparticles alleviate oxidative stress and decreases Nrf-2/HO-1 in D-GALN/LPS induced hepatotoxicity. Biomed. Pharmacother. 73: 80-86. 
He X, Zhang H, Ma Y, Bai W, Zhang Z, Lu K, Ding Y, Zhao Y, Chai Z. 2010. Lung deposition and extrapulmonary translocation of nano-ceria after intratracheal instillation Nanotechnol. 21: 285103/285101-285103/285108.

Hegazy MA, Maklad HM, Samy DM, Abdelmonsif DA, El Sabaa BM, Elnozahy FY. 2017. Cerium oxide nanoparticles could ameliorate behavioral and neurochemical impairments in 6-hydroxydopamine induced Parkinson's disease in rats. Neurochem. Int. 108: 361-371.

Henics T, Wheatley DN. 1999. Cytoplasmic vacuolation, adaptation and cell death: A view on new perspectives and features. Biol. Cell 91: 485-498.

Herd HL, Bartlett KT, Gustafson JA, McGill LD, Ghandehari H. 2015. Macrophage silica nanoparticle response is phenotypically dependent. Biomaterials 53: 574-582.

Higashimori A, Watanabe T, Nadatani Y, Takeda S, Otani K, Tanigawa T, Yamagami H, Shiba M, Tominaga K, Fujiwara Y, Arakawa T. 2016. Mechanisms of NLRP3 inflammasome activation and its role in NSAID-induced enteropathy. Mucosal Immunol. 9: 659-668.

Hijaz M, Das S, Mert I, Gupta A, Al-Wahab Z, Tebbe C, Dar S, Chhina J, Giri S, Munkarah A, Seal S, Rattan R. 2016. Folic acid tagged nanoceria as a novel therapeutic agent in ovarian cancer. BMC Cancer 16: 220/221-220/214.

Hirst SM, Karakoti A, Singh S, Self W, Tyler R, Seal S, Reilly CM. 2013. Bio-distribution and in vivo antioxidant effects of cerium oxide nanoparticles in mice. Environ. Toxicol. 28: 107118.

Hoppstädter J, Seif M, Dembek A, Cavelius C, Huwer H, Kraegeloh A, Kiemer AK. 2015. M2 polarization enhances silica nanoparticle uptake by macrophages. Front. Pharmacol. 6: 1-12.

Hosseini A, Sharifi AM, Abdollahi M, Najafi R, Baeeri M, Rayegan S, Cheshmehnour J, Hassani S, Bayrami Z, Safa M. 2015. Cerium and yttrium oxide nanoparticles against leadinduced oxidative stress and apoptosis in rat hippocampus. Biol. Trace Elem. Res. 164: 8089.

Jones SW, Roberts RA, Robbins GR, Perry JL, Kai MP, Chen K, Bo T, Napier ME, Ting JP, Desimone JM, Bear JE. 2013. Nanoparticle clearance is governed by Th1/Th2 immunity and strain background. J. Clin. Invest. 123: 3061-3073.

Khaksar MR, Rahimifard M, Baeeri M, Hassani S, Moeini-Nodeh S, Kebriaeezadeh A, Maqbool F, Navaei-Nigjeh M, Abdollahi M. 2017. Protective effects of cerium oxide and yttrium oxide nanoparticles on reduction of oxidative stress induced by sub-acute exposure to diazinon in the rat pancreas. J. Trace Elem. Med. Biol. 41: 79-90.

Khurana A, Tekula S, Godugu C. 2018. Nanoceria suppresses multiple low doses of streptozotocin-induced Type 1 diabetes by inhibition of Nrf2/NF- $\kappa \mathrm{B}$ pathway and reduction of apoptosis. Nanomed. (London) 13: 1905-1922.

Larade K, Storey KB. 2004. Accumulation and translation of ferritin heavy chain transcripts following anoxia exposure in a marine invertebrate. J. Exp. Biol. 207: 1353-1360.

Lebedev IA, Kulyako YM. 1978. [Study of the complexing of cerium(III) and cerium(IV) in concentrated phosphoric acid solutions]. Zh. Neorg. Khim. 23: 3215-3224.

Lee T-C, Ho IC. 1995. Modulation of cellular antioxidant defense activities by sodium arsenite in human fibroblasts. Arch. Toxicol. 69: 498-504.

Li K, Zhao S, Ma J. 2005. Study on solubility of cerium (IV) phosphate. J. Rare Earths 23: 5153.

Lin Q-R, Li C-G, Zha Q-B, Xu L-H, Pan H, Zhao G-X, Ouyang D-Y, He X-H. 2016. Gossypol induces pyroptosis in mouse macrophages via a non-canonical inflammasome pathway. Toxicol. Appl. Pharmacol. 292: 56-64. 
Liu T, Yamaguchi Y, Shirasaki Y, Shikada K, Yamagishi M, Hoshino K, Kaisho T, Takemoto K, Suzuki T, Kuranaga E, Ohara O, Miura M. 2014. Single-cell imaging of caspase-1 dynamics reveals an all-or-none inflammasome signaling response. Cell Rep. 8: 974-982.

Liu X, Byrne RH. 1997. Rare earth and yttrium phosphate solubilities in aqueous solution. Geochim. Cosmochim. Acta 61: 1625-1633.

Ma JY, Young SH, Mercer RR, Barger M, Schwegler-Berry D, Ma JK, Castranova V. 2014. Interactive effects of cerium oxide and diesel exhaust nanoparticles on inducing pulmonary fibrosis. Toxicol. Appl. Pharmacol. 278: 135-147.

MacParland SA, Tsoi KM, Ouyang B, Ma XZ, Manuel J, Fawaz A, Ostrowski MA, Alman BA, Zilman A, Chan WC, McGilvray ID. 2017. Phenotype determines nanoparticle uptake by human macrophages from liver and blood. ACS Nano 11: 2428-2443.

Masui T, Hirai H, Imanaka N, Adachi G, Sakata T, Mori H. 2002. Synthesis of cerium oxide nanoparticles by hydrothermal crystallization with citric acid. J. Mater. Sci. Lett. 21: 489491.

McDaniel DK, Jo A, Ringel-Scaia VM, Coutermarsh-Ott S, Rothschild DE, Powell MD, Zhang R, Long TE, Oestreich KJ, Riffle JS, Davis RM, Allen IC. 2017. TIPS pentacene loaded PEO-PDLLA core-shell nanoparticles have similar cellular uptake dynamics in M1 and M2 macrophages and in corresponding in vivo microenvironments. Nanomedicine (N. Y., NY, U. S.) 13: 1255-1266.

Molina RM, Konduru NV, Jimenez RJ, Pyrgiotakis G, Demokritou P, Wohlleben W, Brain JD. 2014. Bioavailability, distribution and clearance of tracheally instilled, gavaged or injected cerium dioxide nanoparticles and ionic cerium. Environ. Sci.: Nano 1: 561-573.

Negahdary M, Ranjbar A, Asadi A. 2012. The toxicity effect of cerium oxide nanoparticles on ALT, AST and ALP enzymes in male rat. Ann. Biol. Res. 3: 4386-4392.

Nemmar A, Yuvaraju P, Beegam S, Fahim MA, Ali BH. 2017. Cerium oxide nanoparticles in lung acutely induce oxidative stress, inflammation, and DNA damage in various organs of mice. Oxid. Med. Cell. Longev. 2017: 9639035.

Northrop-Clewes CA. 2008. Interpreting indicators of iron status during an acute phase response - lessons from malaria and human immunodeficiency virus. Ann. Clin. Biochem. 45: 18-32.

O'Brien M, Moehring D, Muñoz-Planillo R, Núñez G, Callaway J, Ting J, Scurria M, Ugo T, Bernad L, Cali J, Lazar D. 2017. A bioluminescent caspase-1 activity assay rapidly monitors inflammasome activation in cells. J. Immunol. Methods 447: 1-13.

OECD. (2010) List of manufactured nanomaterials and list of endpoints for phase one of the sponsorship programme for the testing of manufactured nanomaterials: Revision. In: Joint Meeting of the Chemicals Committee and the Working Party on Chemicals, Pesticides and Biotechnology Environment Directorate, Pesticides and Biotechnology (Ed), Series on the safety of manufactured nanomaterials, Organisation for Economic Co-operation and Development, http://www.oecd.org/officialdocuments/displaydocumentpdf/?cote=env/jm/mono(2010)46\&d oclanguage $=$ en. $($ visited 5/11/2020)

Okinaga T, Ariyoshi W, Nishihara T. 2015. Aggregatibacter actinomycetemcomitans invasion induces interleukin- $1 \beta$ production through reactive oxygen species and cathepsin $\mathrm{B}$. J. Interferon Cytokine Res. 35: 431-440.

Park K, Park J, Lee H, Choi J, Yu W-J, Lee J. 2018. Toxicity and tissue distribution of cerium oxide nanoparticles in rats by two different routes: single intravenous injection and single oral administration. Arch. Pharm. Res. 41: 1108-1116. 
Pietsch EC, Chan JY, Torti FM, Torti SV. 2003. Nrf2 mediates the induction of ferritin H in response to xenobiotics and cancer chemopreventive dithiolethiones. J. Biol. Chem. 278: 2361-2369.

Poma A, Ragnelli AM, de Lapuente J, Ramos D, Borras M, Aimola P, Di Gioacchino M, Santucci S, De Marzi L. 2014. In vivo inflammatory effects of ceria nanoparticles on CD-1 mouse: Evaluation by hematological, histological, and TEM analysis. J. Immunol. Res.: 361419/361411-361419/361414.

Popov AL, Zaichkina SI, Popova NR, Rozanova OM, Romanchenko SP, Ivanova OS, Smirnov AA, Mironova EV, Selezneva II, Ivanov VK. 2016. Radioprotective effects of ultra-small citrate-stabilized cerium oxide nanoparticles in vitro and in vivo. RSC Advances 6: 106141106149.

Pourkhalili N, Hosseini A, Nili-Ahmadabadi A, Hassani S, Pakzad M, Baeeri M, Mohammadirad A, Abdollahi M. 2011. Biochemical and cellular evidence of the benefit of a combination of cerium oxide nanoparticles and selenium to diabetic rats. World J. Diabetes 2: 204-210.

Primiano T, Kensler TW, Kuppusamy P, Zweier JL, Sutter TR. 1996. Induction of hepatic heme oxygenase- 1 and ferritin in rats by cancer chemopreventive dithiolethiones. Carcinogenesis 17: 2291-2296.

Ranjbar A, Taheri AM, Soleimani AS, Firozian F, Heidary DH, Ganji M, Seyedabadi S, Ganji M. 2018. Role of cerium oxide nanoparticles in a paraquat-induced model of oxidative stress: Emergence of neuroprotective results in the brain. J. Mol. Neurosci. 66: 420-427.

Rice KM, Nalabotu SK, Kolli MB, Manne NDPK, Nandyala G, Arvapalli R, Ma JY, Blough ER. 2015. Exposure to cerium oxide nanoparticles is associated with activation of mitogenactivated protein kinases signaling and apoptosis in rat lungs. J. Prev. Med. Public Health 48: 132-141.

Rocca A, Moscato S, Ronca F, Nitti S, Mattoli V, Giorgi M, Ciofani G. 2015. Pilot in vivo investigation of cerium oxide nanoparticles as a novel anti-obesity pharmaceutical formulation. Nanomedicine 11: 1725-1734.

Rojas S, Gispert JD, Abad S, Buaki-Sogo M, Victor VM, Garcia H, Herance JR. 2012. In vivo biodistribution of amino-functionalized ceria nanoparticles in rats using positron emission tomography. Mol. Pharm. 9: 3543-3550.

Saifi MA, Sangomla S, Khurana A, Godugu C. 2019. Protective effect of nanoceria on cisplatininduced nephrotoxicity by amelioration of oxidative stress and pro-inflammatory mechanisms. Biol. Trace Elem. Res. 189: 145-156.

Sangomla S, Saifi MA, Khurana A, Godugu C. 2018. Nanoceria ameliorates doxorubicin induced cardiotoxicity: Possible mitigation via reduction of oxidative stress and inflammation. J. Trace Elem. Med. Biol. 47: 53-62.

Schiaffonati L, Tiberio L. 1997. Gene expression in liver after toxic injury: analysis of heat shock response and oxidative stress-inducible genes. Liver 17: 183-191.

Seredenin SB, Khlopushina TG, Zherdev VP. 1990. Pharmacokinetics and metabolism of antipyrine in inbred mice. Pharm. Chem. J. 24: 620-623.

Seredenin SB, Lapitskaya AS, Nadorov SA, Kudrin VS, Badyshtov BA. 2000. Multidimensional assessment of differences in monoamine metabolism in $\mathrm{C} 57 \mathrm{Bl} / 6$ and BALB/c mice. Bull. Exp. Biol. Med. 129: 487-490.

Shi H, Ebrahim AS, Berger EA. 2018. A contrast in pathogenic responses between C57BL/6J and BALB/cJ mice using a model of retinal injury. Am. J. Pathol. 188: 2717-2728. 
Shubin AV, Demidyuk IV, Komissarov AA, Rafieva LM, Kostrov SV. 2016. Cytoplasmic vacuolization in cell death and survival. Oncotarget 7: 55863-55889.

Singh S. 2016. Cerium oxide based nanozymes: Redox phenomenon at biointerfaces. Biointerphases 11: 04B202/201-204B202/212.

Sorber CWJ, Van Dort JB, Ringeling PC, Cleton-Soeteman MI, De Bruijn WC. 1990. Quantitative energy-filtered image analysis in cytochemistry. II. Morphometric analysis of element-distribution images. Ultramicroscopy 32: 69-79.

Stoecklein VM, Osuka A, Ishikawa S, Lederer MR, Wanke-Jellinek L, Lederer JA. 2015. Radiation exposure induces inflammasome pathway activation in immune cells. J. Immunol. 194: 1178-1189.

Tsuji Y, Ayaki H, Whitman SP, Morrow CS, Torti SV, Torti FM. 2000. Coordinate transcriptional and translational regulation of ferritin in response to oxidative stress. Mol. Cell. Biol. 20: 5818-5827.

Uh S-T, Koo SM, Kim Y, Kim K, Park S, Jang AS, Kim D, Park C-S, Kim YH. 2017. The activation of NLRP3-inflammsome by stimulation of diesel exhaust particles in lung tissues from emphysema model and RAW 264.7 cell line. Korean J. Intern. Med. 32: 865-874.

Vásquez B, Sandoval C, Smith RL, del Sol M. 2015. Effects of early and late adverse experiences on morpho-quantitative characteristics of Sprague-Dawley rat spleen subjected to stress during adulthood. Int. J. Clin. Exp. Pathol. 8: 3624-3635.

Xu PT, Antonic V, Jackson IL, Zodda A, Zhang X, Vujaskovic Z, Maidment BW, 3rd, Das S, Seal S. 2016. Cerium oxide nanoparticles: A potential medical countermeasure to mitigate radiation-induced lung injury in CBA/J mice. Radiat. Res. 185: 516-526.

Xue L, He X, Li Y, Qu M, Zhang Z. 2013. Pulmonary toxicity of ceria nanoparticles in mice after intratracheal instillation. J. Nanosci. Nanotechnol. 13: 6575-6580.

Yokel RA. 2020. Nanoparticle brain delivery: A guide to verification methods. Nanomed. (London) 15: 409-432.

Yokel RA, Au TC, MacPhail R, Hardas SS, Butterfield DA, Sultana R, Goodman M, Tseng MT, Dan M, Haghnazar H, Unrine JM, Graham UM, Wu P, Grulke EA. 2012. Distribution, elimination, and biopersistence to 90 days of a systemically introduced $30 \mathrm{~nm}$ ceriaengineered nanomaterial in rats. Toxicol. Sci. 127: 256-268.

Yokel RA, Florence RL, Unrine JM, Tseng MT, Graham UM, Wu P, Grulke EA, Sultana R, Hardas SS, Butterfield DA. 2009. Biodistribution and oxidative stress effects of a systemically-introduced commercial ceria engineered nanomaterial. Nanotoxicology 3: 234248.

Yokel RA, Hancock ML, Cherian B, Brooks AJ, Ensor ML, Vekaria HJ, Sullivan PG, Grulke EA. 2019a. Simulated biological fluid exposure changes nanoceria's surface properties but not its biological response. Eur. J. Pharm. Biopharm. 144: 252-265.

Yokel RA, Hancock ML, Grulke EA, Unrine JM, Dozier AK, Graham UM. 2019b. Carboxylic acids accelerate acidic environment-mediated nanoceria dissolution. Nanotoxicology 13: 455-475.

Yokel RA, Tseng MT, Dan M, Unrine JM, Graham UM, Wu P, Grulke EA. 2013. Biodistribution and biopersistence of ceria engineered nanomaterials: Size dependence. Nanomedicine 9: 398-407.

Yokel RA, Unrine JM, Wu P, Wang B, Grulke E. 2014. Nanoceria biodistribution and retention in the rat are not greatly influenced by dosing schedule, dose, or shape. Environ. Sci.: Nano 1: $549-560$. 
You S-A, Wang Q. 2005. Ferritin in atherosclerosis. Clin. Chim. Acta 357: 1-16.

Younis A, Chu D, Li S. (2016) Cerium oxide nanostructures and their applications. InTech, pp. 53-68, https://www.intechopen.com/books/functionalized-nanomaterials/cerium-oxidenanostructures-and-their-applications. (visited 5/11/2020)

Zeth K, Hoiczyk E, Okuda M. 2016. Ferroxidase-mediated iron oxide biomineralization: Novel pathways to multifunctional nanoparticles. Trends Biochem. Sci. 41: 190-203.

Zhang P, Ma Y, Zhang Z, He X, Zhang J, Guo Z, Tai R, Zhao Y, Chai Z. 2012. Biotransformation of ceria nanoparticles in cucumber plants. ACS Nano 6: 9943-9950.

Zheng B, Lai R, Li J, Zuo Z. 2017. Critical role of P2X7 receptors in the neuroinflammation and cognitive dysfunction after surgery. Brain. Behav. Immun. 61: 365-374. 
Table 1. Spleen differences due to mouse strain and nanoceria treatment, based on evaluation of light microscopic images. * = Significantly different from control BALB/c mice.

\begin{tabular}{|l|c|c|}
\hline Termination time & C57BL/6 mice & BALB/c mice \\
\hline \multicolumn{2}{|c|}{ Spleen vacuolation differences: mouse strain and nanoceria - compared to vehicle-treated mice } \\
\hline $0.5,1,3,6, \& 24 \mathrm{~h}$ & $\begin{array}{c}\text { Not different from vacuolation in } \\
\text { BALB/c mice }\end{array}$ & $\begin{array}{c}\text { Not different from vacuolation in } \\
\text { C57BL/6 mice }\end{array}$ \\
\hline \multicolumn{2}{|c|}{ Spleen white pulp cell density: nanoceria-treated mice as a percent of vehicle-treated mice } \\
\hline $0.5 \mathrm{~h}$ & 106 & 105 \\
\hline $1 \mathrm{~h}$ & 123 & 109 \\
\hline $3 \mathrm{~h}$ & 107 & $132 *$ \\
\hline $6 \mathrm{~h}$ & 111 & $107 *$ \\
\hline $24 \mathrm{~h}$ & 104 & $130^{*}$ \\
\hline
\end{tabular}


Figure 1.
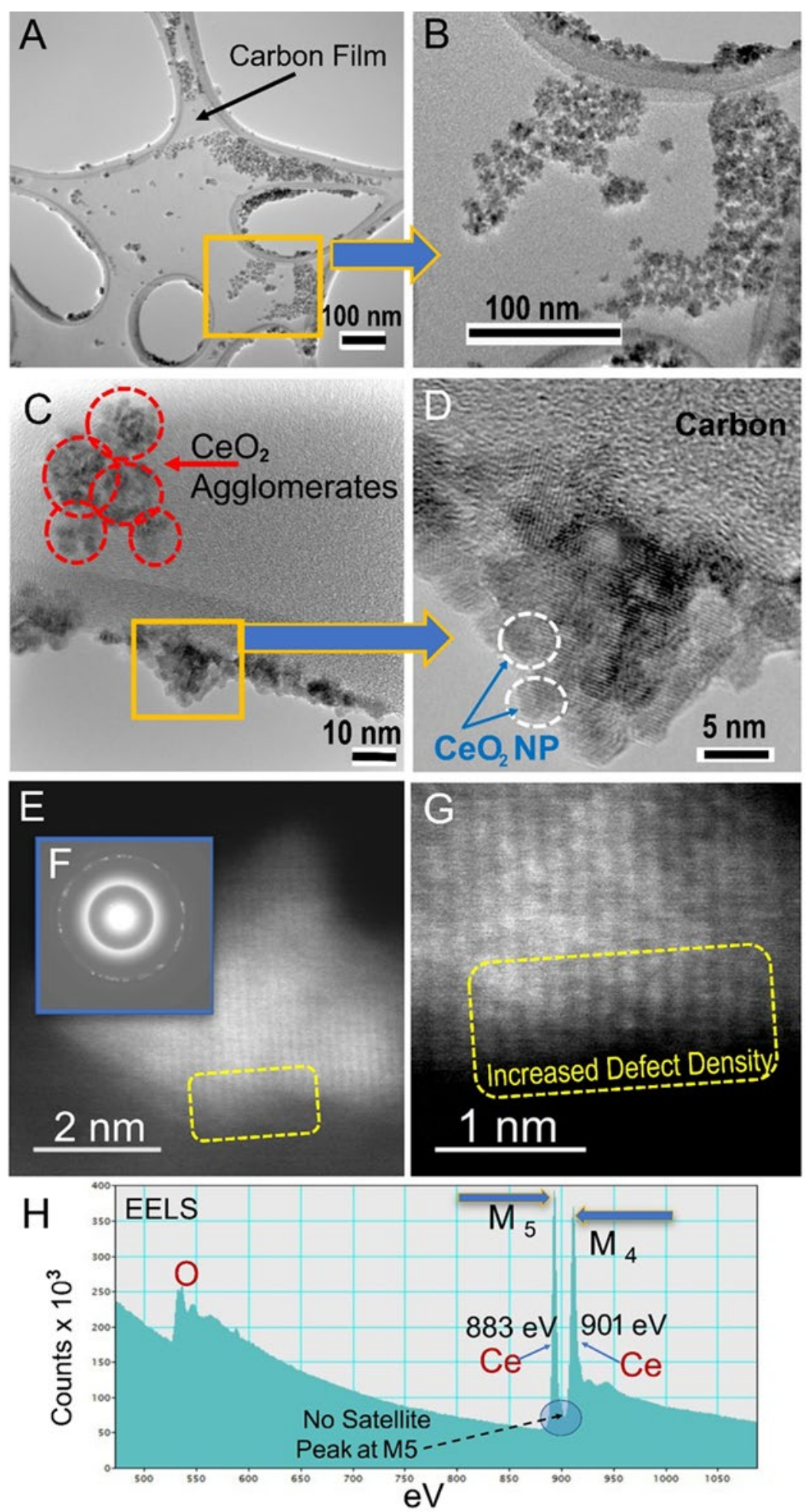
Figure 1. Physicochemical properties of the as-dosed nanoceria. The as-dosed nanoceria is shown in TEM images with increasing magnification as agglomerates on lacy carbon support (A, $\mathrm{B}, \mathrm{C}$ and $\mathrm{D}$ ). E and $\mathrm{G}$ are STEM images at atomic resolution displaying rows of atoms (primary particles are crystalline as indicated by d-spacings in $\mathrm{E}$ and $\mathrm{G}$ and the $\mathrm{X}$-ray diffractogram in $\mathrm{F}$ with characterisic ring structure signifying faces $\{100\}$ and $\{111\})$. The surface of the primary nanoceria has an increased defect density (lower atom density) as indicated by the yellow squared areas in $\mathrm{E}$ and $\mathrm{G}$. The EELS measurement in $\mathrm{H}$ was obtained at the nanoceria surface inside the yellow squared area and the M5 and M4 Ce peaks at $883 \mathrm{eV}$ and $901 \mathrm{eV}$, respectively, are marked. The taller M5 peak indicates presence of predominantly $\mathrm{Ce}^{+++}$. The M5 peak is missing a satellite peak (at $895 \mathrm{eV}$ ) which is characteristic of $\mathrm{Ce}^{+++}$dominance. $\mathrm{Ce}^{+++}$dominance is caused by the increased defect density or oxygen vacancies in the nanoceria crystal surface. 
Figure 2 .
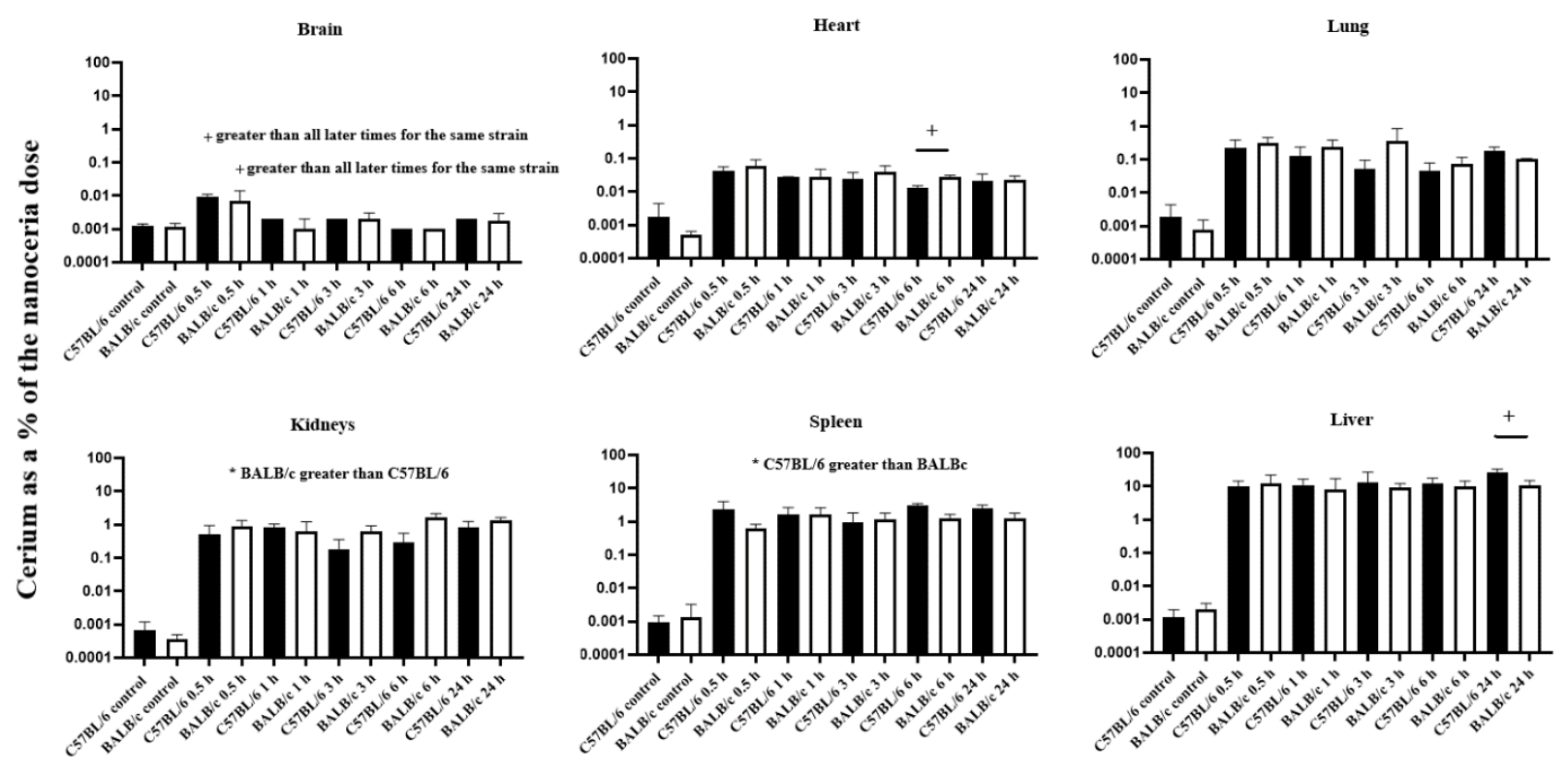

Figure 2. Organ cerium as a percent of the injected dose. Results are mean \pm S.D. of cerium, determined by ICP-MS. They are expressed as a percent of the injected nanoceria dose, in the whole organ, for the mouse strain, treatment and sacrifice times shown. Results are from five control (vehicle treated) and three nanoceria-treated mice. $+=$ Statistically different by protected LSD. * = statistically different in two way ANOVA, at $\mathrm{p}<0.05$. 
Figure 3.

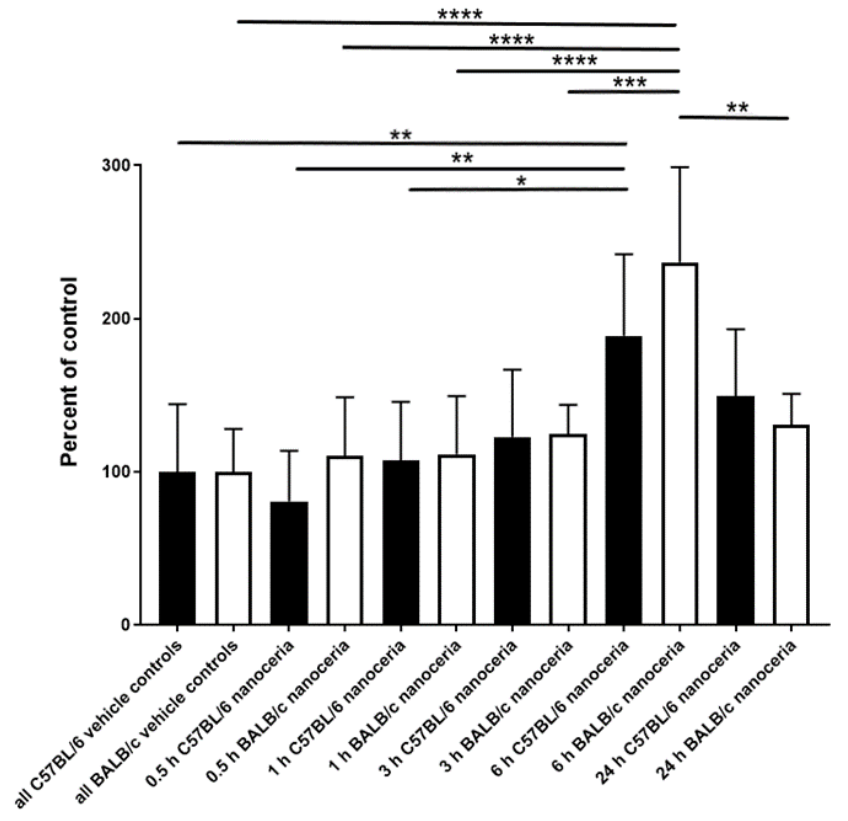

Figure 3. Liver caspase-1 levels. Results are mean \pm S.D of 10 control (vehicle treated) mice and six nanoceria-treated mice. $*, * *, * * *$, and $* * *$ indicate statistically significant differences at $\mathrm{p}<$ $0.05,0.01,0.001$, and 0.0001 , respectively. 
Figure 4.
C57BL/6 mice
BALB/c mice

$0.5 \mathrm{~h}$
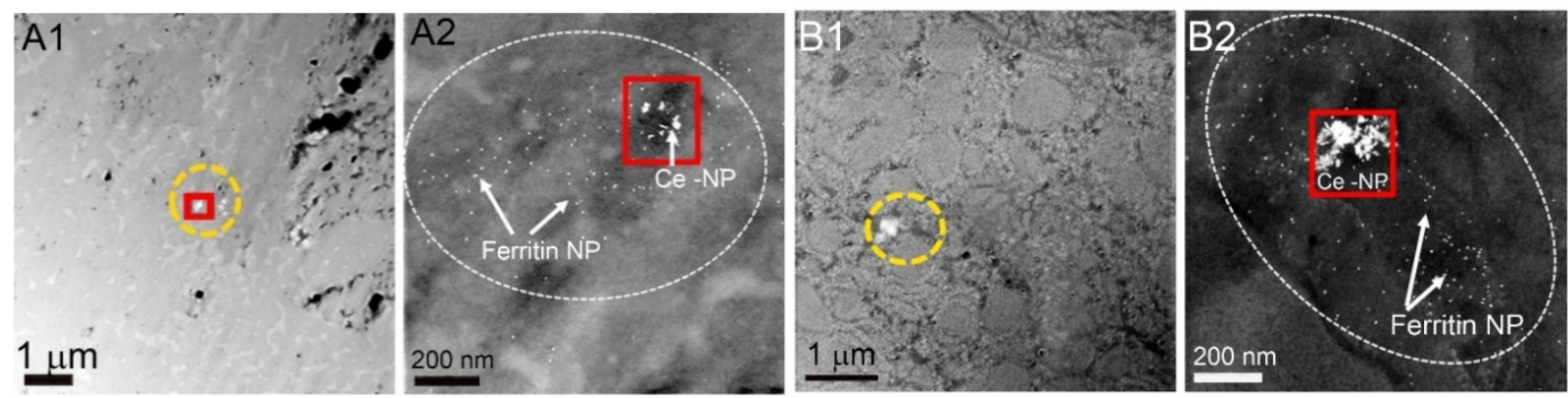

$1 \mathrm{~h}$
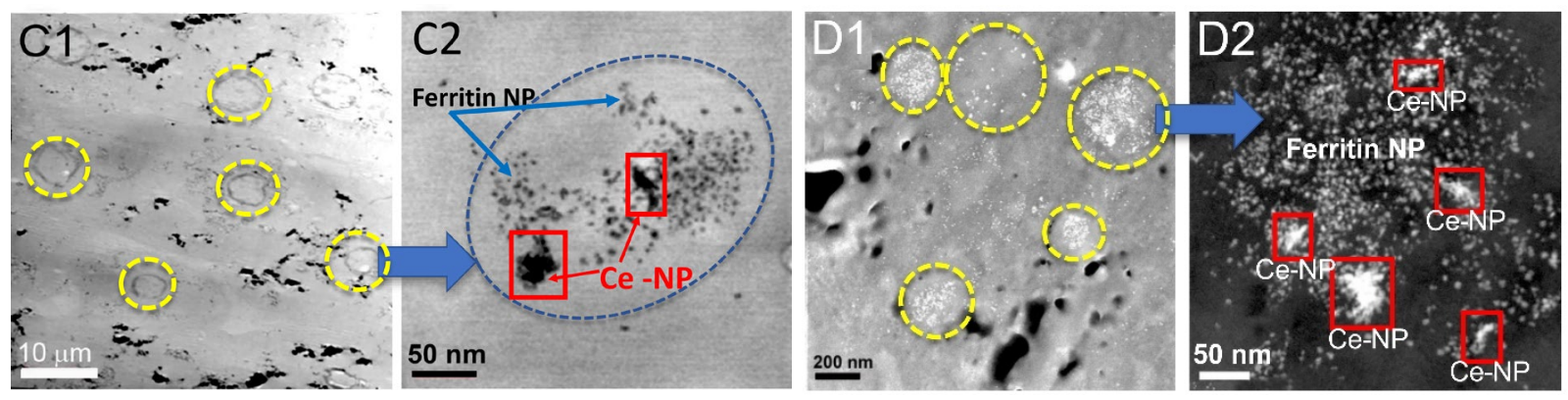

$6 \mathrm{~h}$
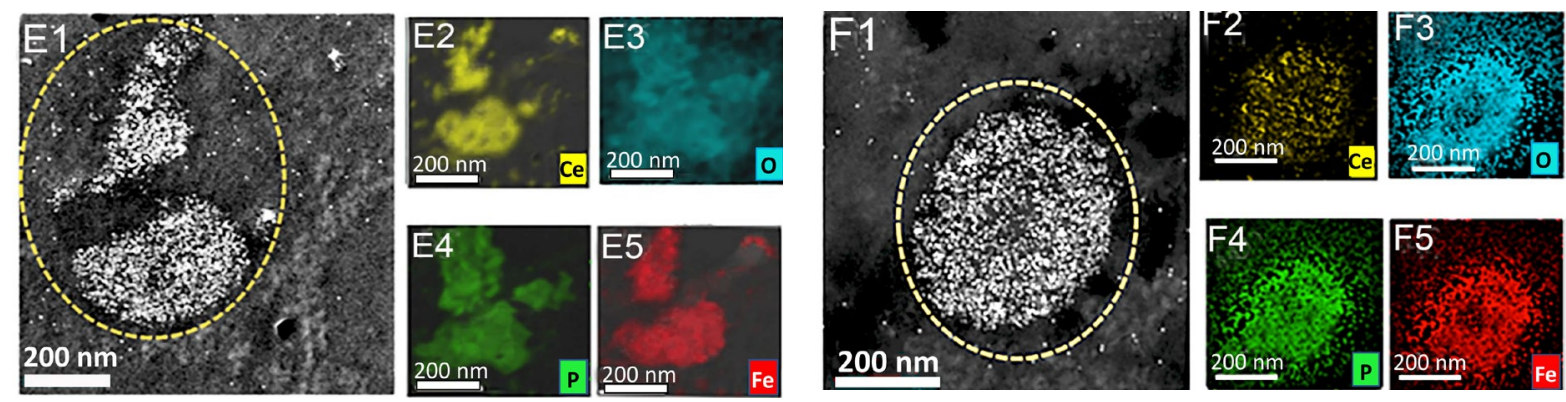

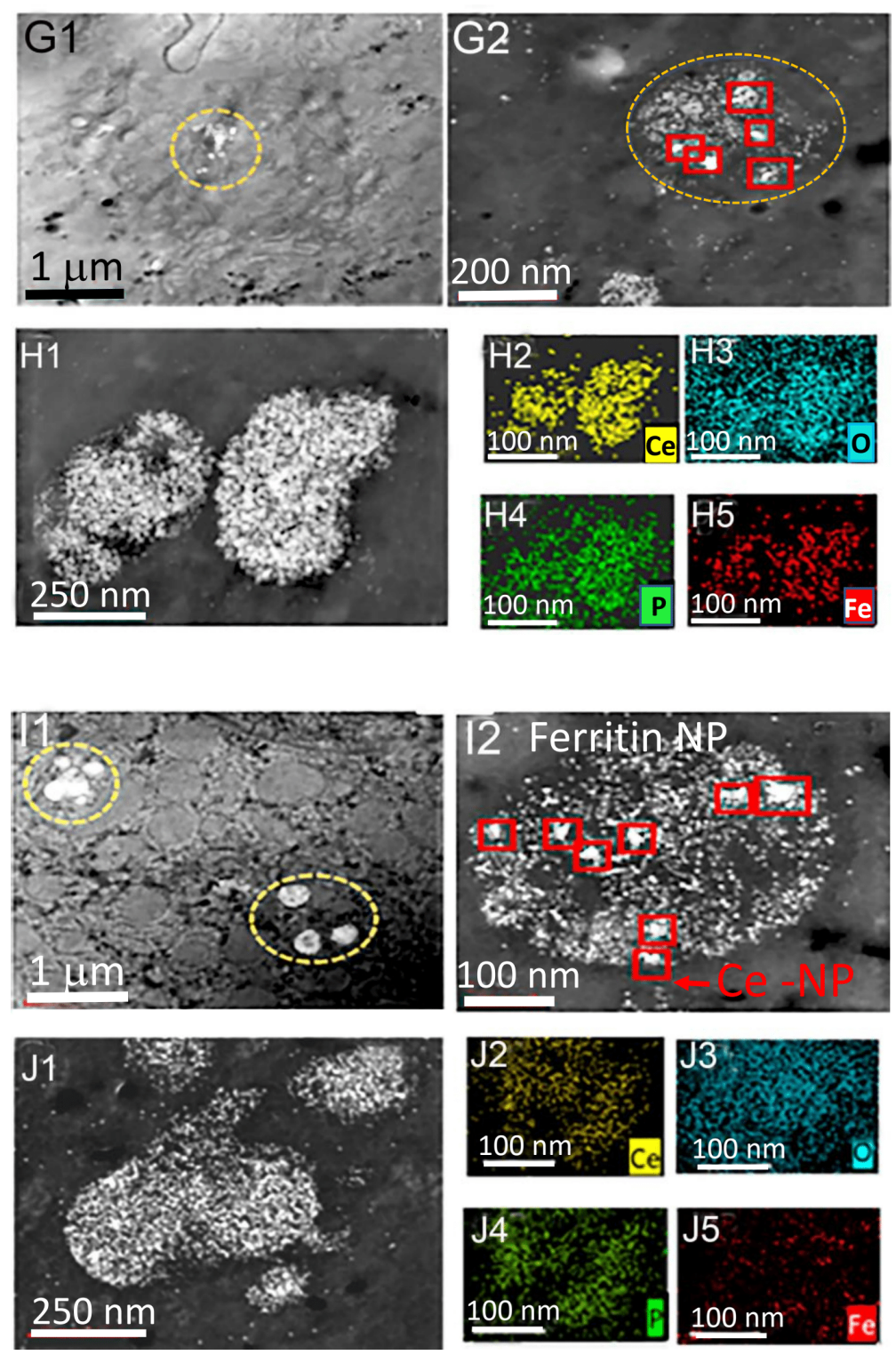

Figure 4. Nanoceria uptake in the liver of $\mathrm{C} 57 \mathrm{BL} / 6$ and $\mathrm{BALB} / \mathrm{c}$ mice at various times after nanoceria injection. A1, A2, B1, B2, and C1 are TEM images. C2, D1, D2, E1, F1, G1, G2, H1, $\mathrm{I} 1, \mathrm{I} 2$, and $\mathrm{J} 1$ are STEM images. $0.5,1,6$, and $24 \mathrm{~h}$ indicate the time between nanoceria injection and mouse termination. Intracellular nanoceria (Ce-NP, inside yellow circles and red squares) is shown at $0.5 \mathrm{~h}$ (A and B), $1 \mathrm{~h}$ (C and D), $6 \mathrm{~h}$ (E and F), and $24 \mathrm{~h}$ (G to J). Nanoceria, which occurs in agglomerates, looks dark in TEM and white in STEM imaging mode and is surrounded by copious ferritin (Ferritin NP) accumulations (A2, B2, C2, D2, G2 and I2). Individual ferritin nanoparticles are $\sim 5$ to $10 \mathrm{~nm}$. Elemental maps (EDS mapping) are shown for corresponding regions imaged in STEM mode and show verification of cerium and oxygen and co-localization of cerium, oxygen, phosphorus, and iron after $6 \mathrm{~h}$ (Figure 4E1(STEM) with maps E2-5 and 4F1 (STEM) with maps 4F2-5) and after $24 \mathrm{~h}$ (Figure 4H1 (STEM) with maps 4H2-5 and 4J1 (STEM) with maps 4J2-5) after nanoceria injection. 
Figure 5.
C57BL/6 mice
$\mathrm{BALB} / \mathrm{c}$ mice

$0.5 \mathrm{~h}$

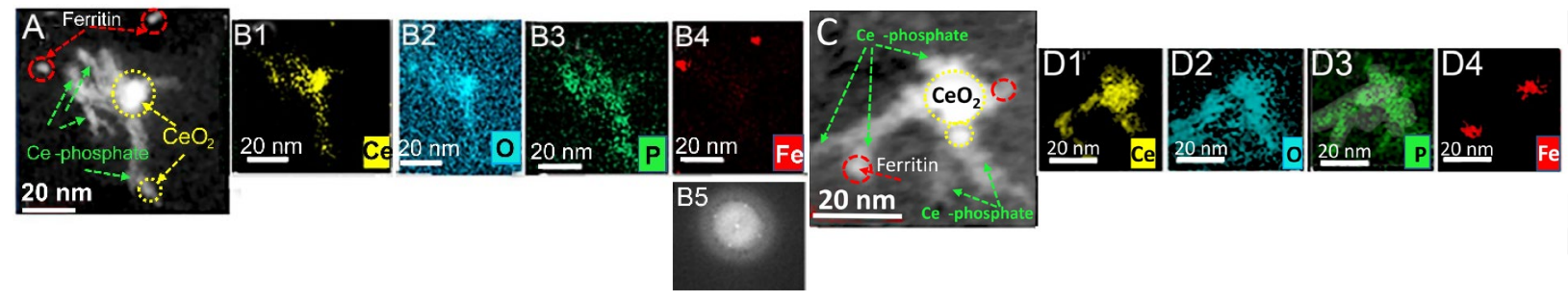

$6 \mathrm{~h}$

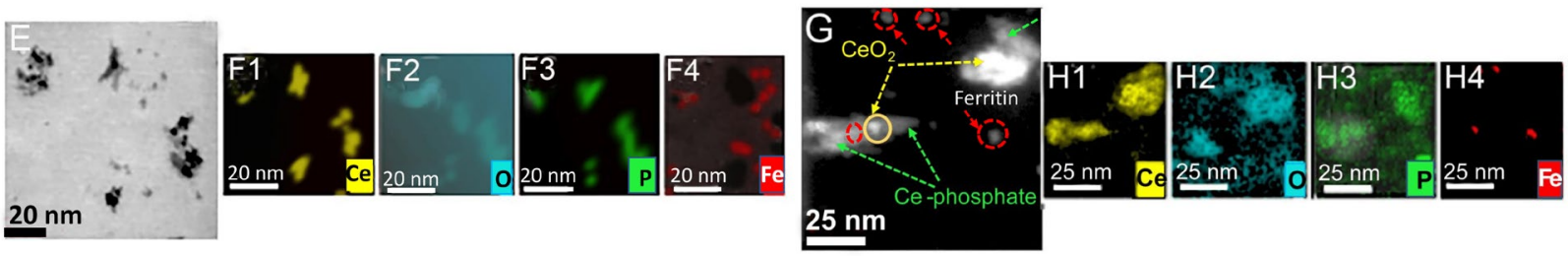

$24 \mathrm{~h}$

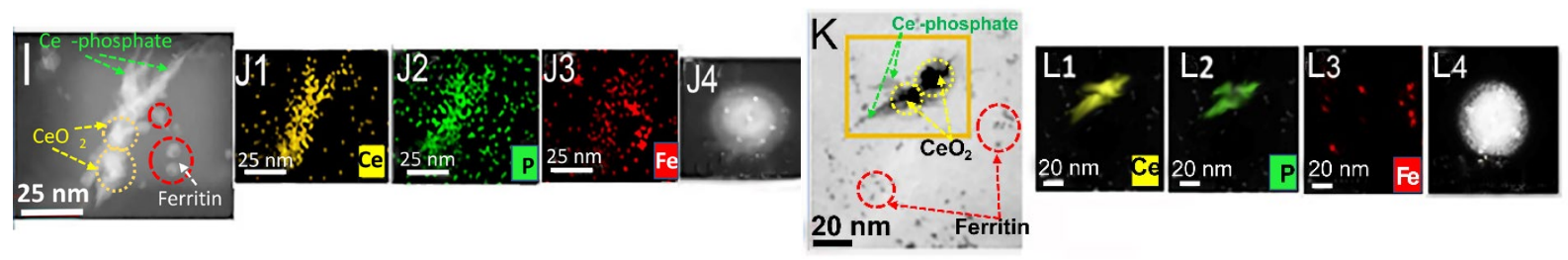

Figure 5. Nanoceria was bioprocessed in the liver. Examples of bioprocessed nanoceria 0.5, 6 , and $24 \mathrm{~h}$ after its injection are shown as STEM (A, C, G, and I) and TEM (E and K) images and associated EDS elemental maps (B5, J4, and L4). The STEM images indicate the presence of needles around the nanoceria. The nanoceria and needles in the STEM images are marked by arrows and shown in the corresponding EDS maps as $\mathrm{Ce}, \mathrm{O}$, and $\mathrm{P}$ rich regions. Only the needles are P-rich and are identified with X-ray diffraction pattern (B5 and L4) as Ce-phosphate. The diffraction patterns also confirm the crystalline nature of the needles. The nanoceria are replaced by Ce-phosphate during bioprocessing. The nanoceria and Ce-phosphate nanoneedles are surrounded by copious ferritin nanoparticles (5A, C, G, I, and K) which are $\sim 5$ to $10 \mathrm{~nm}$ and are identified in the corresponding EDS Fe maps (B4, D4, F4, H4, J3, and L3). Cellular regions that 
do not include nanoceria/Ce-phosphate have a very low density of ferritin while the ferritin density around nanoceria/Ce-phosphate grains is significantly higher. 
Figure 6.

Normal biomineralized iron nanoparticle distribution

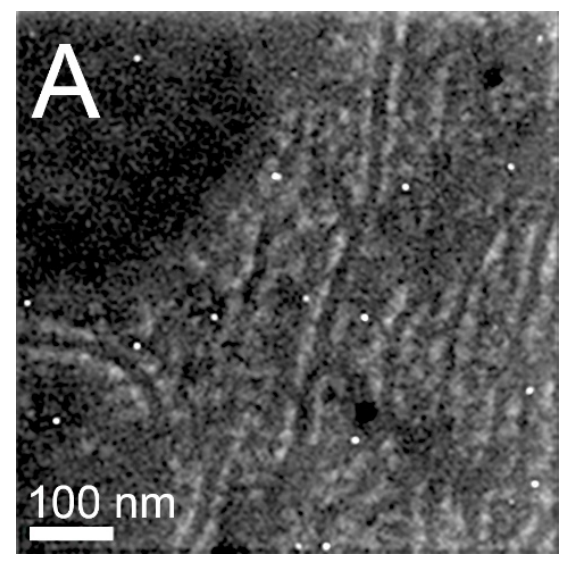

C57BL/6 mice

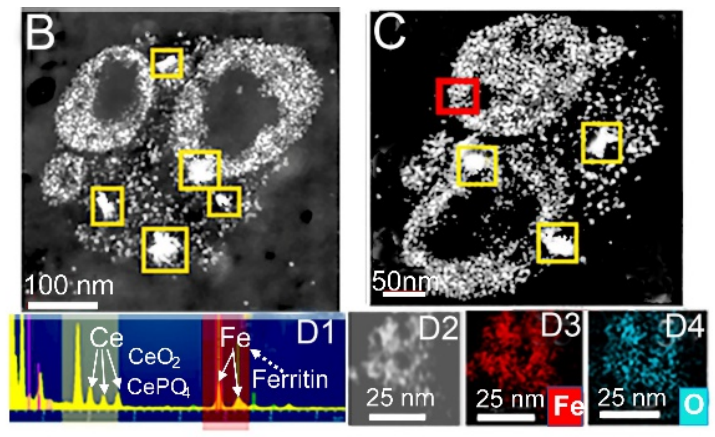

$\mathrm{BALB} / \mathrm{c}$ mice

Figure 6. Biomineralized iron nanoparticles (ferritin) accumulated in mouse liver after nanoceria injection and occur in locally enriched zones around nanoceria. Biomineralized iron nanoparticles are shown in the STEM images (A, B, and C) as white $\sim 5$ to $10 \mathrm{~nm}$ spots while the nanoceria agglomerates are larger and denser (indicated in $\mathrm{B}$ and $\mathrm{C}$ with yellow squares). Tissue regions that are not invaded by nanoceria have a low concentration or "normal" distribution of ferritin (A). B and $\mathrm{C}$ are at $24 \mathrm{~h}$ post-nanoceria dosing. Both ferritin and nanoceria associate with lysosomal regions or granules (B and C). Some granules are completely filled with ferritin and nanoceria, while others appear to have a core-shell type occupancy in the case of the C57BL/6 mice. Image D1 is an EDS spectrum identifying both Ce and $\mathrm{Fe}$ and D2-4 are EDS maps obtained from the region defined by the red box in $\mathrm{C}$. The $\mathrm{BALB} / \mathrm{c}$ mice liver uptake of nanoceria is shown in STEM images E1 to E2 which show EELS mapping for $\mathrm{Ce}$ and $\mathrm{P}$ and a corresponding EDS map of Fe in E3 which indicates that iron 
accumulation as ferritin occurs in the vicinity of Ce-phosphate after bioprocessing of nanoceria in the liver. 
Figure 7.

A

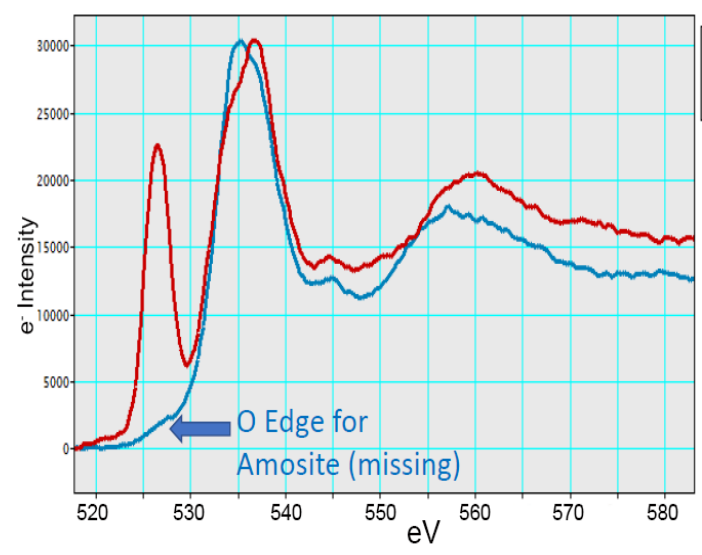

C

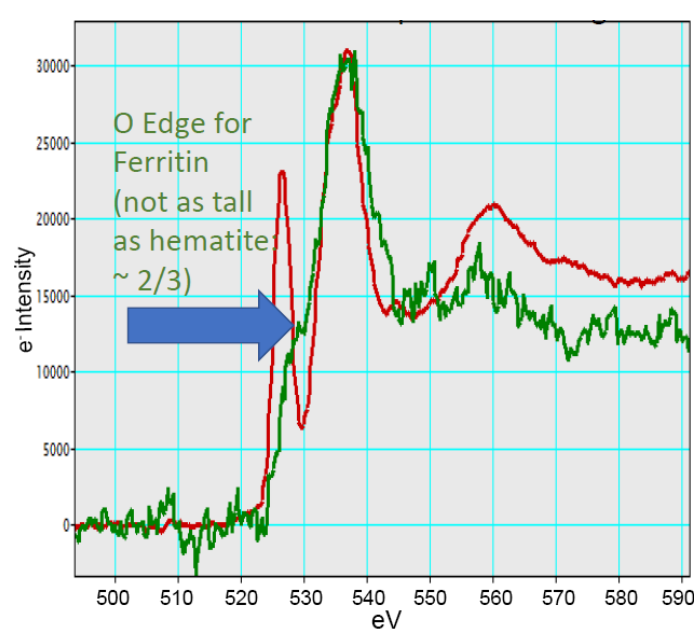

$\mathrm{B}$
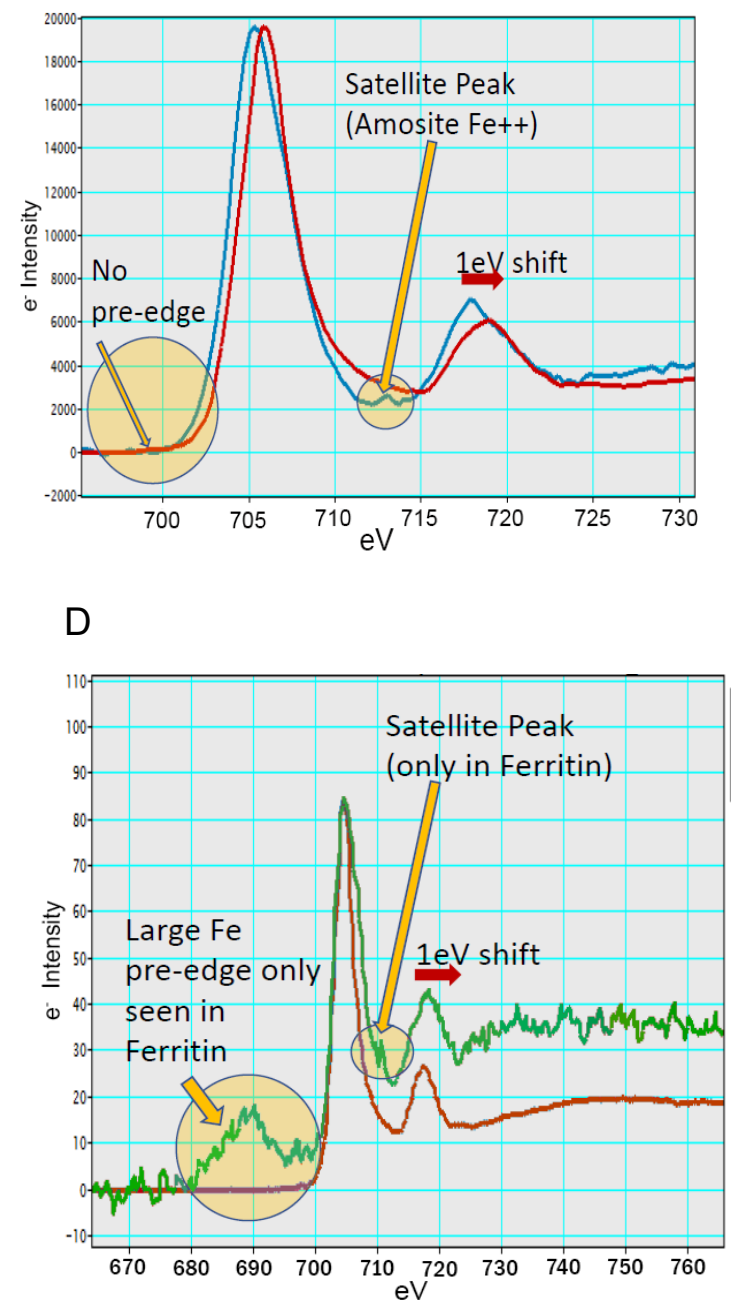

Figure 7. EELS oxygen and iron analyses of $\mathrm{Fe}^{++}$- and $\mathrm{Fe}^{+++}$-containing standard minerals Amosite $\left(\mathrm{Fe}^{++}\right)$and Hematite $\left(\mathrm{Fe}^{+++}\right)$and the biomineralized iron nanoparticles (ferritin) that accumulate around nanoceria in liver as shown in Figure $6 \mathrm{~B}$ and $\mathrm{C}$. A shows the oxygen edge of amosite (blue line) and hematite (red line) indicating a large edge in the $\mathrm{Fe}^{+++}$(hematite) but not $\mathrm{Fe}^{++}$- (amosite) containing standard. B shows the edge for iron with the standard materials amosite (blue line) and hematite (red line) indicating a satellite peak for the $\mathrm{Fe}^{++}$- but not $\mathrm{Fe}^{+++}$containing standard mineral. There is also a slight energy shift of $\sim 1 \mathrm{eV}$ (B) to distinguish $\mathrm{Fe}^{++}$ versus $\mathrm{Fe}^{+++}$rich phases. $\mathrm{C}$ shows the oxygen edge of ferritin that formed in the liver (green line) and hematite standard (red line). The EELS comparison in $C$ shows an $\sim 1 / 3$ reduction in the oxygen edge of ferritin compared to the standard hematite. D illustrates the iron edge of ferritin (green line) and hematite standard (red line) showing the presence of pre-edge and satellite peaks in ferritin only and the alignment of the core edges of ferritin and hematite standard. 
Supplemental Figure 1. see separate file

Supplemental Figure 2. see separate file

Supplemental Figure 3. see separate file 
Supplemental Figure 1. Light microscopic images of liver from representative mice from each treatment condition. All scale bars are $50 \mu \mathrm{m}$.

C57BL/6 mice

Control

Nanoceria, $0.5 \mathrm{~h}$

Nanoceria, $1 \mathrm{~h}$
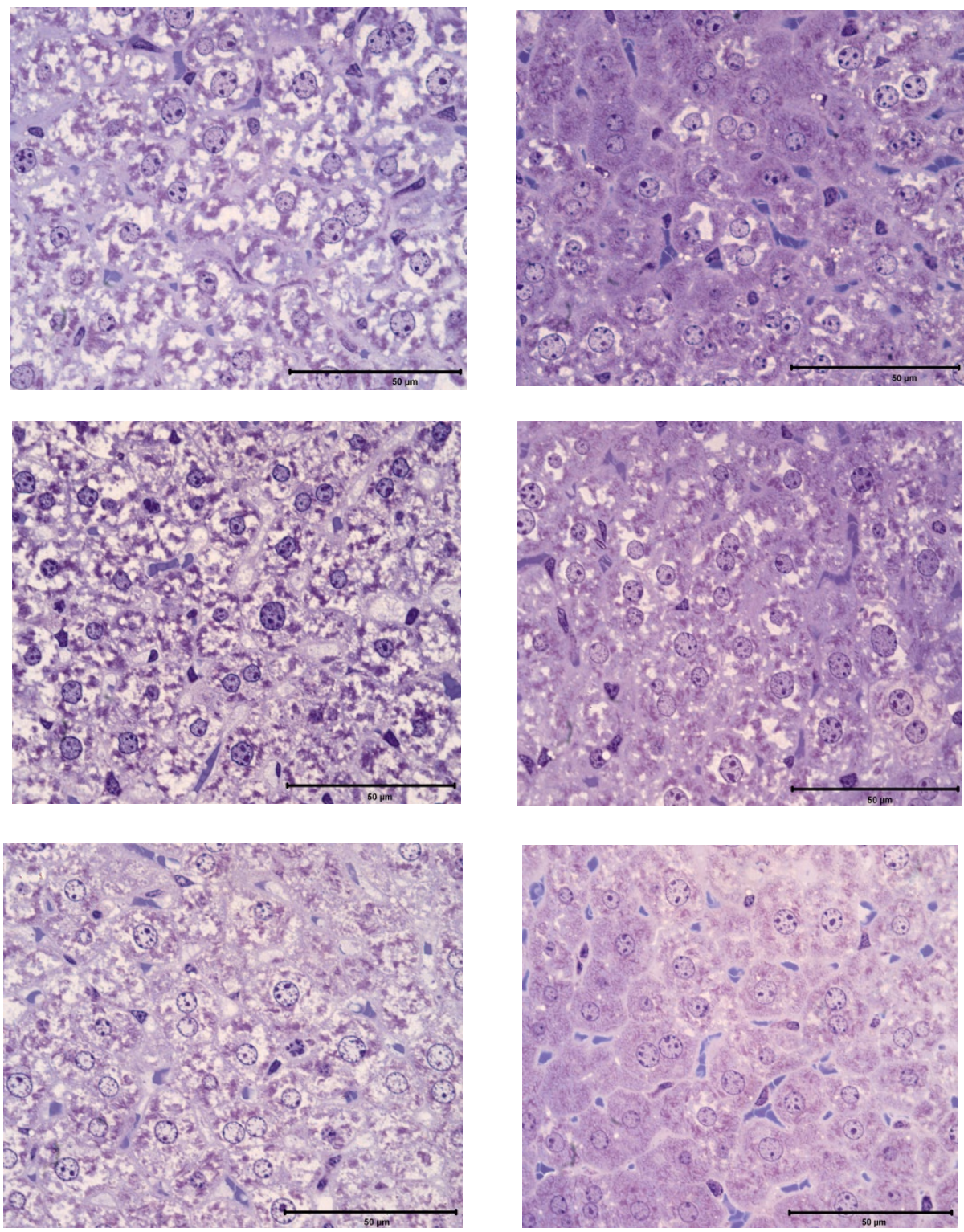
Nanoceria, $3 \mathrm{~h}$
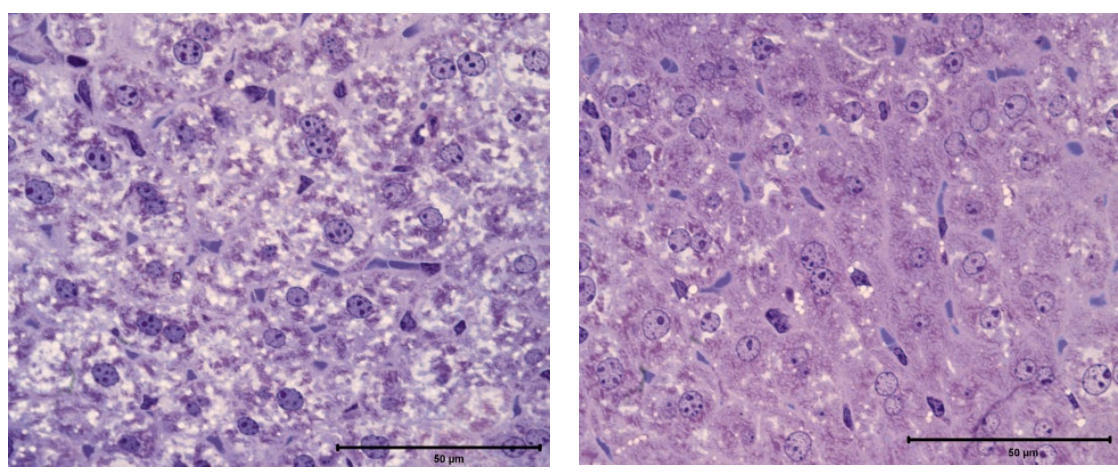

Nanoceria, 6 h
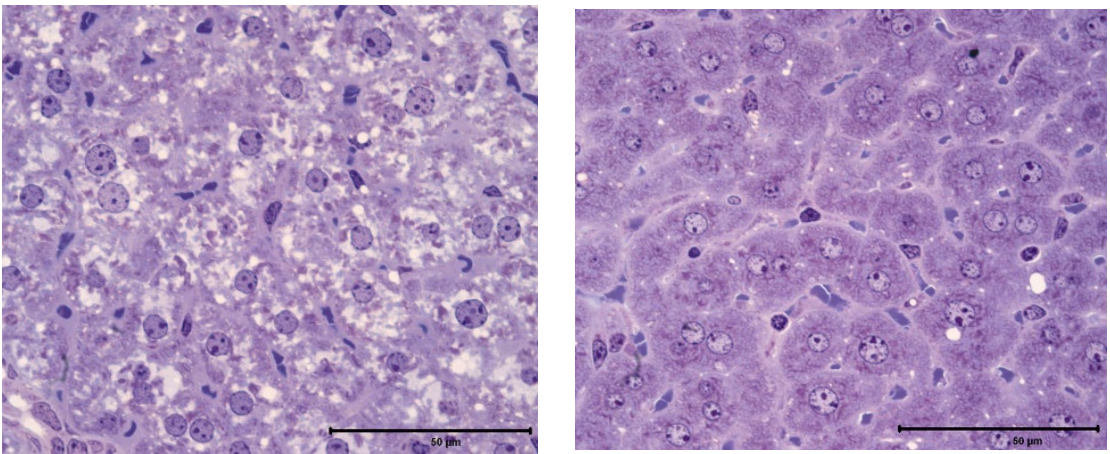

Nanoceria, $24 \mathrm{~h}$
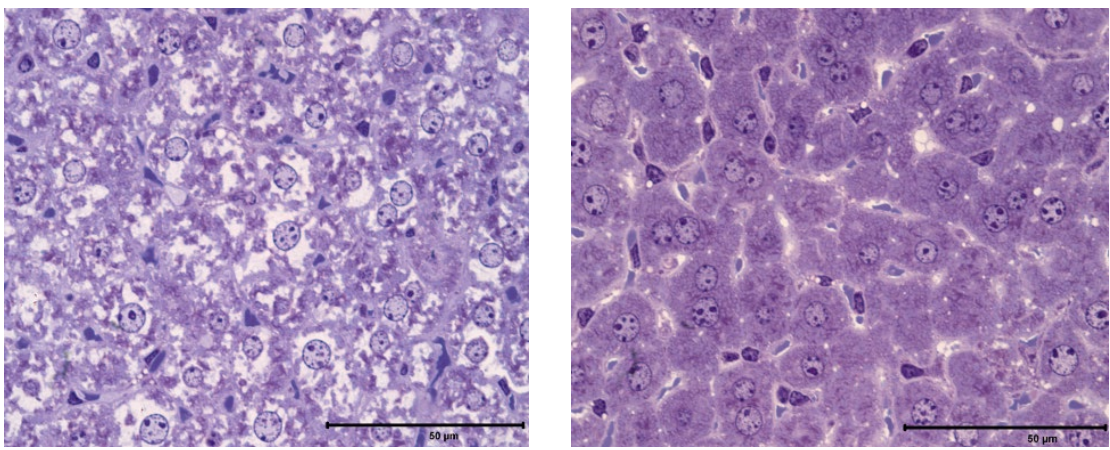
Supplemental Figure 2. Light microscopic images of spleen from representative mice from each treatment condition. All scale bars are $50 \mu \mathrm{m}$.

C57BL/6 mice

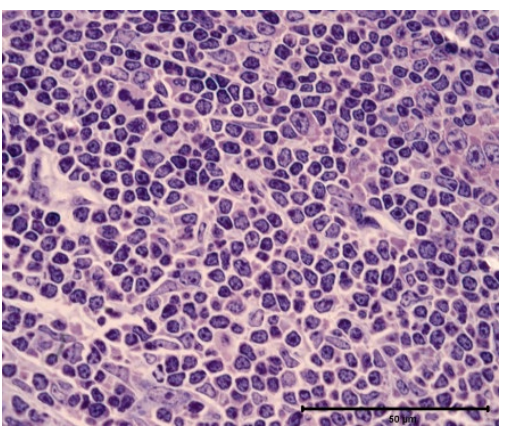

Nanoceria, $0.5 \mathrm{~h}$

Nanoceria, $1 \mathrm{~h}$

Nanoceria, $3 \mathrm{~h}$
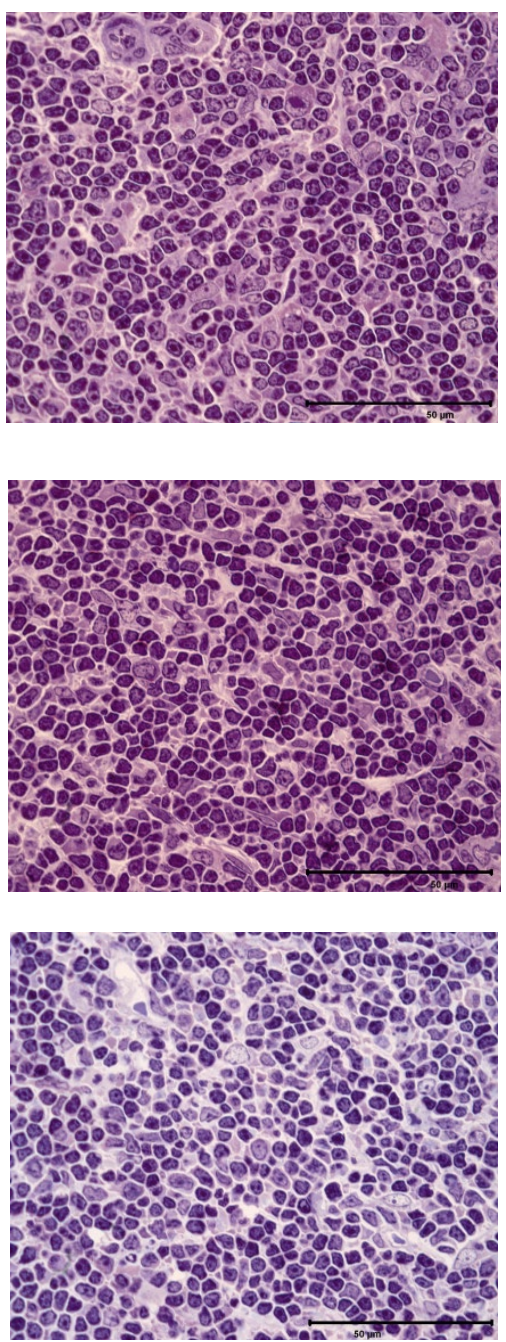

$\mathrm{BALB} / \mathrm{c}$ mice
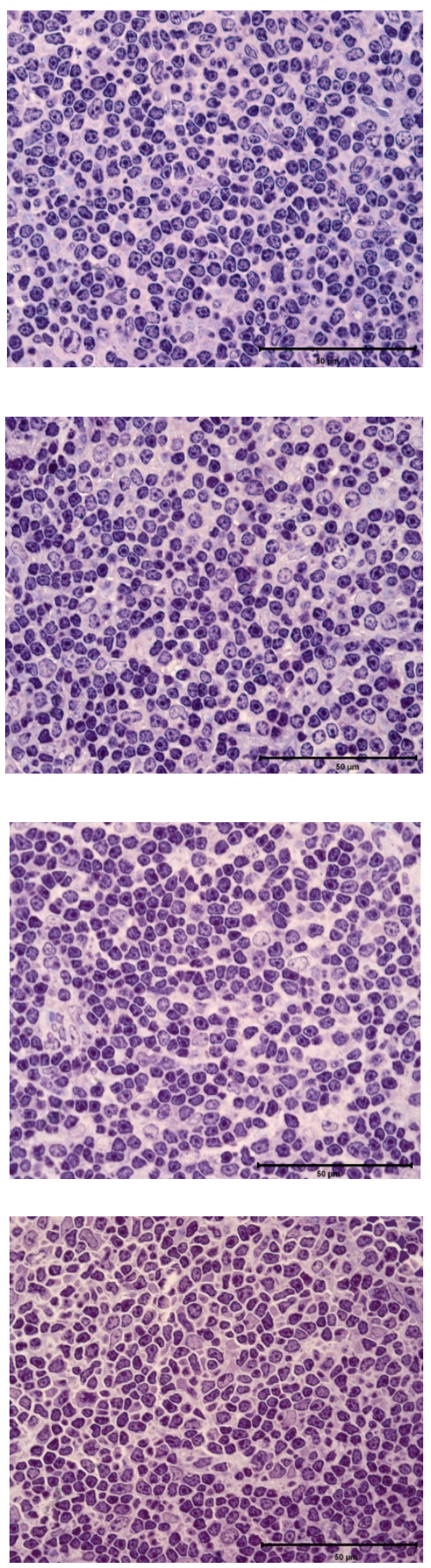
Nanoceria, $6 \mathrm{~h}$
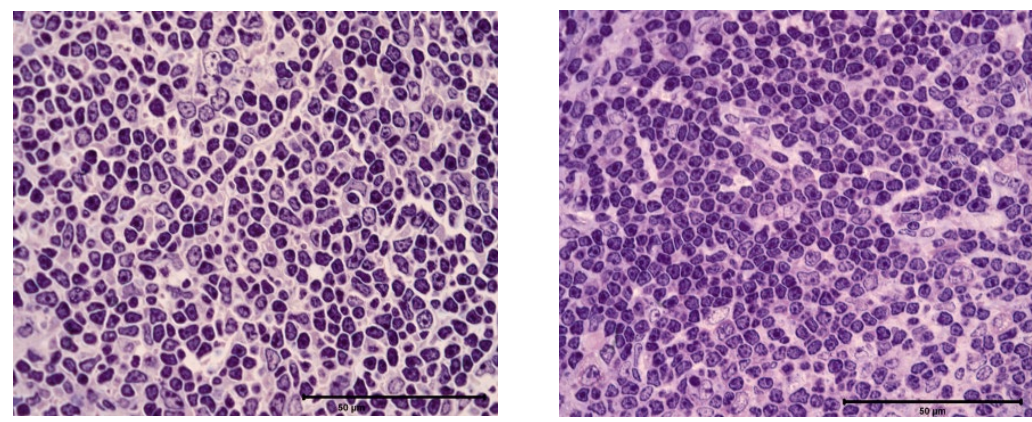

Nanoceria, $24 \mathrm{~h}$
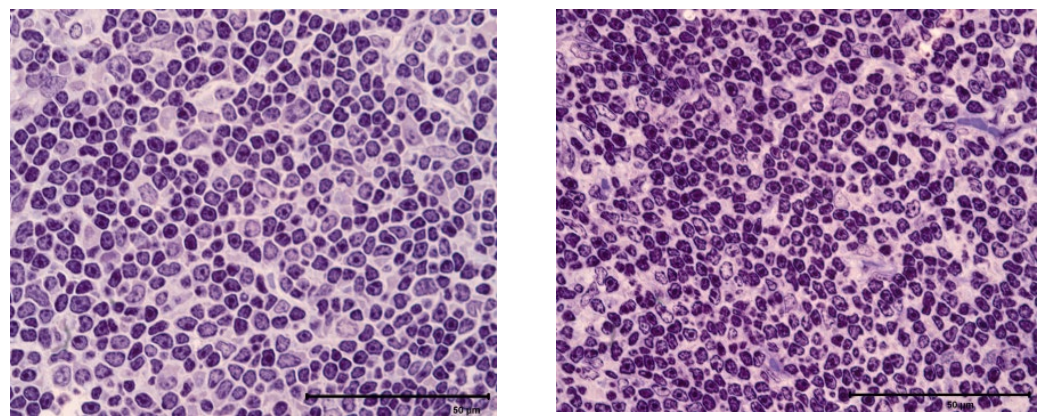


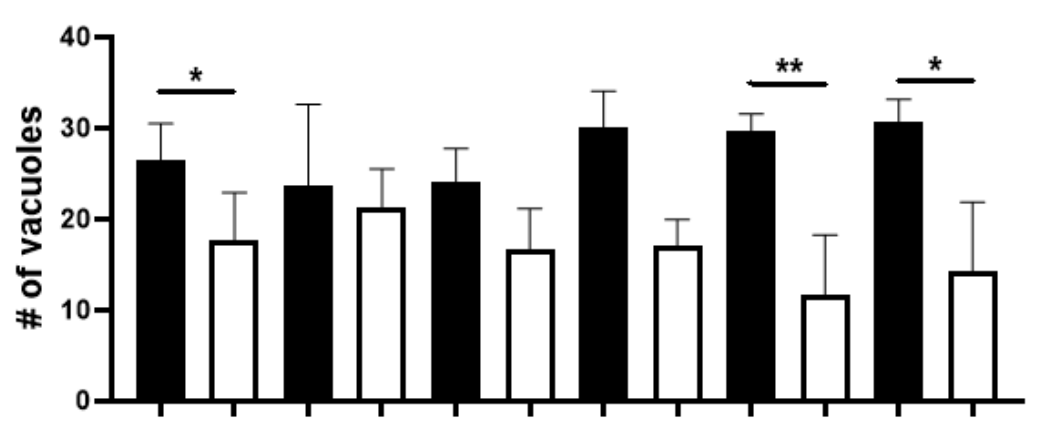

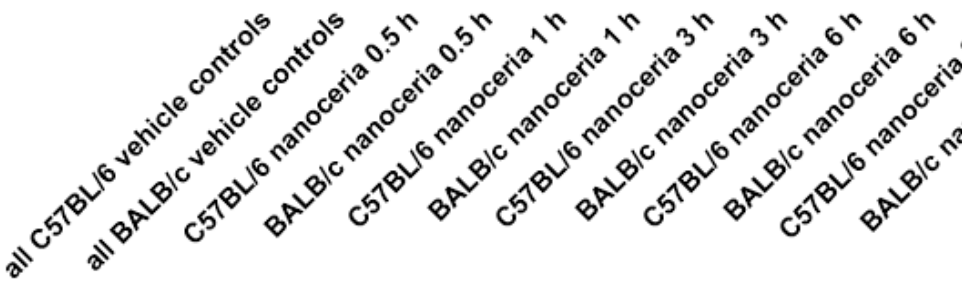
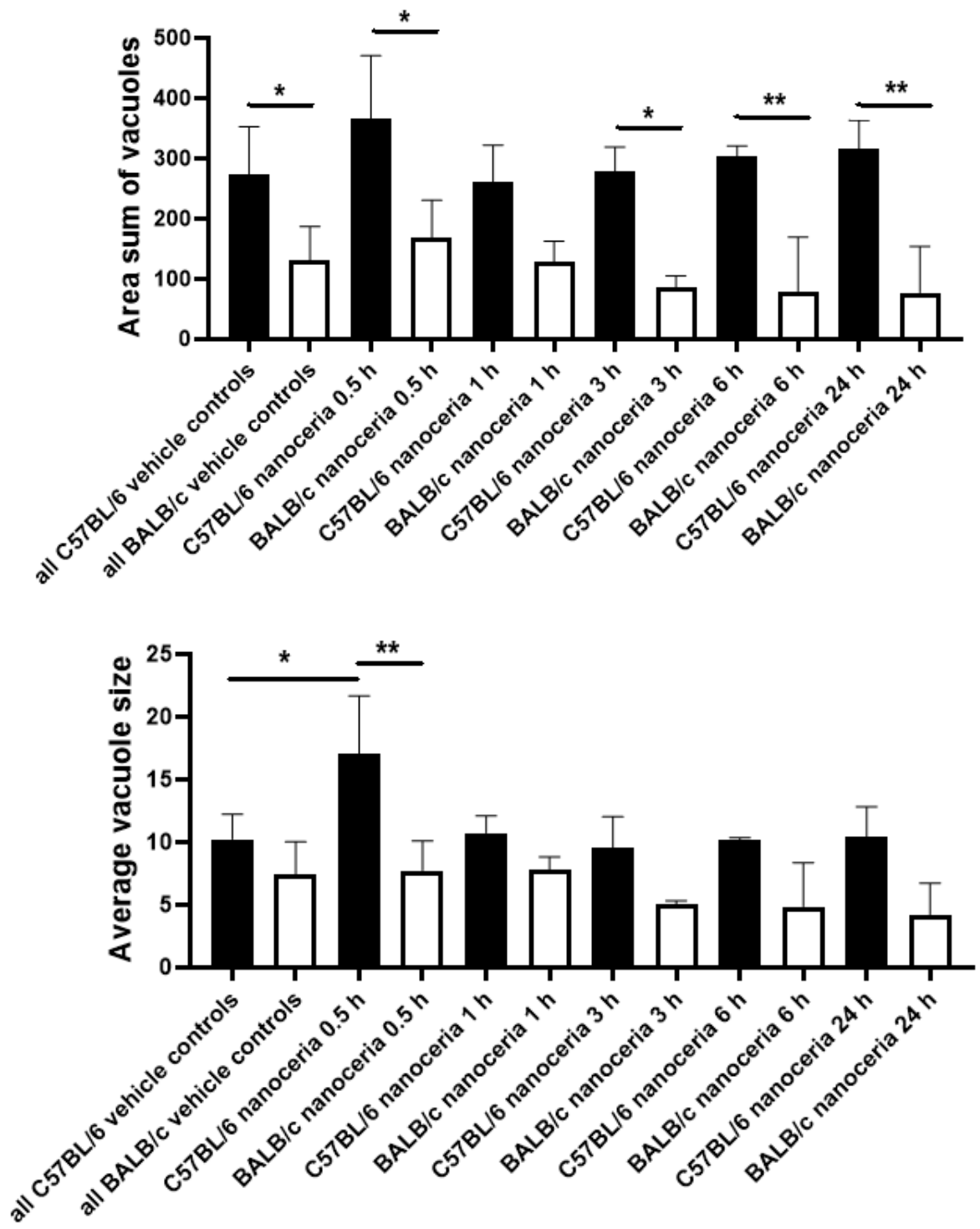

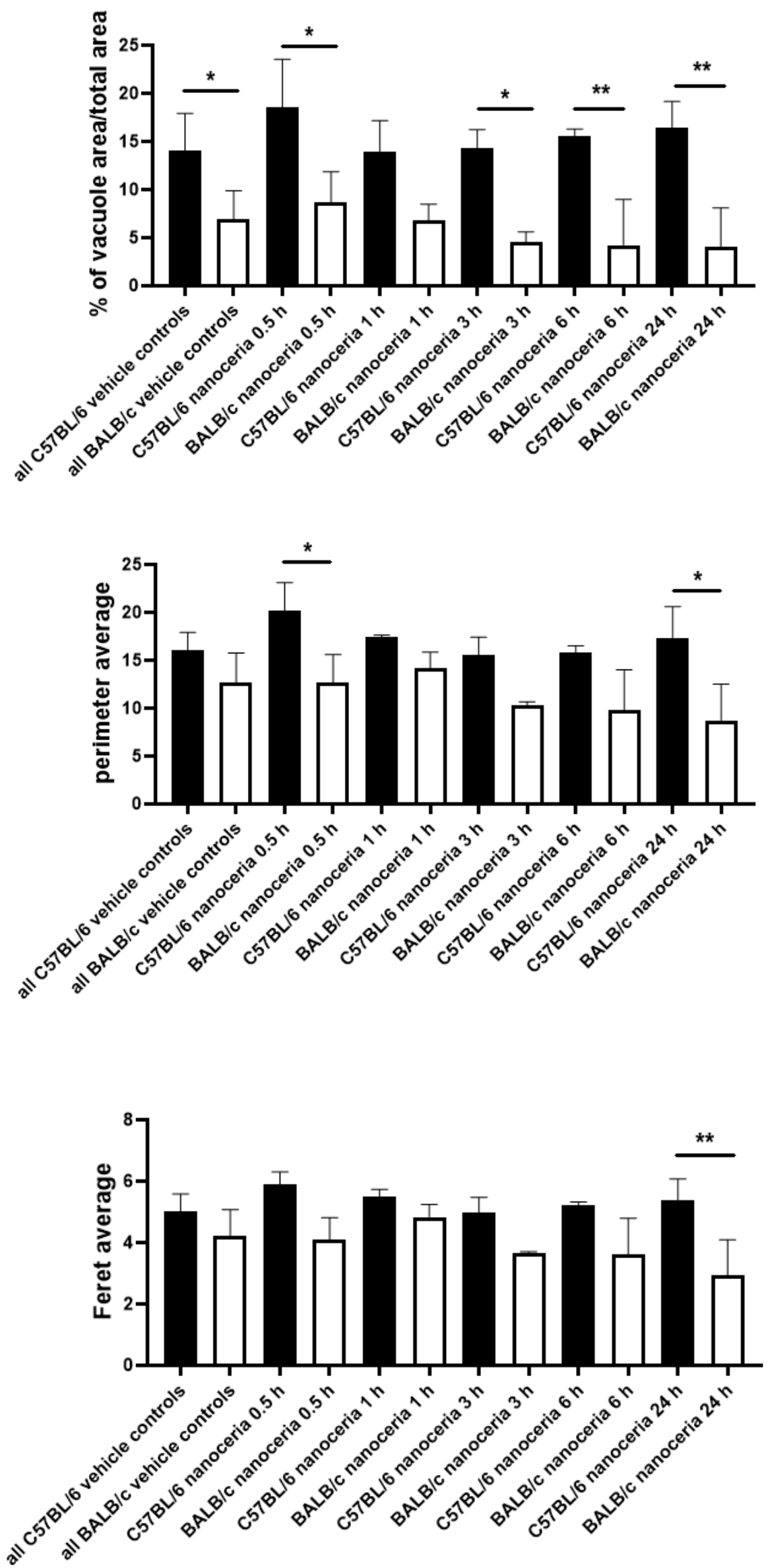

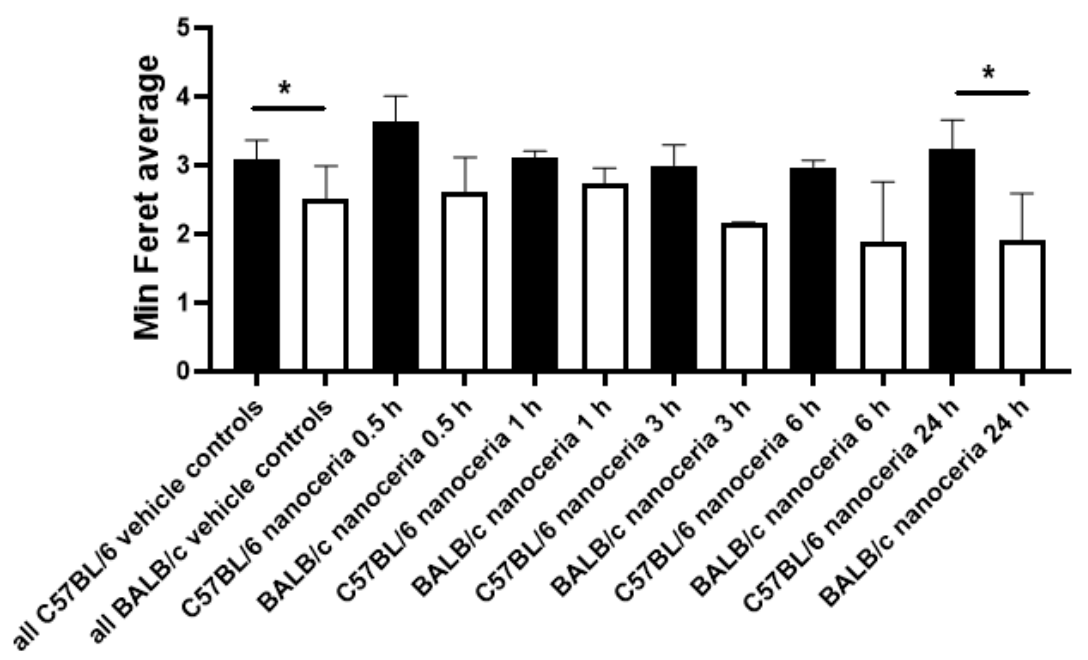

Supplemental Figure 3. Liver vacuole endpoints in C57BL/6 and BALB/C mice as function of mouse strain and nanoceria treatment. Results are the mean \pm S.D. Significant difference by Tukey's multiple comparisons test, after significant ANOVA, ${ }^{*}=p<0.05, * *=p<0.01$. 